\title{
Public Funding of Research into Ethnological Activities in Andalusia (Spain): Boosting the Academic Career of Researchers
}

\author{
Celeste Jiménez de Madariaga*iD, Juan José García del Hoyo*
}

\begin{abstract}
The advent of democracy in Spain and the establishment of the different autonomous communities marked the beginning of a process to transfer political, economic and other competences over Culture and Cultural Heritage. Following its creation in 1984, the Ministry of Culture of the Andalusian Autonomous Government incorporated a Directorate-General for Cultural Assets into its organisational structure and embarked on an ambitious programme of actions to support Andalusian historical heritage, including creation of a management structure, enactment of a specific heritage law and budget allocations for protection tasks. From the outset, a type of heritage little known until then emerged: ethnological heritage. Dynamic actions were also promoted to fund research into this area, including grants for ethnological activities, financing for publications and funding for ethnological symposiums. This paper analyses the different ethnological activities carried out and their funding, and assesses the extent to which this investment favoured the professional development of teaching staff in the field of Social Anthropology in Andalusia, specifying the marginal effects and differentiating them according to gender and university size using binary choice models (Logit).
\end{abstract}

Keywords: public funding; ethnological heritage; research; cultural policies; gender; publication productivity; higher education; promotion.

JEL classification: Z10; Z18; I22.

\section{INTRODUCTION}

The Spanish Constitution of 1978 established a territorial system whereby the country was divided into 'autonomous communities', with profound legal and administrative decentralisation to the extent that the effective functioning of the State resembles that of federal states and even surpasses in many aspects the level of self-government of the states of the USA or the länder of certain European federal republics. The Spanish territory is divided

\footnotetext{
* Department of History, Geography and Anthropology, Faculty of Humanities, University of Huelva, Spain; e-mail: celeste@uhu.es.

Department of Economics, Faculty of Business Studies and Tourism, University of Huelva, Spain; e-mail: hoyo@uhu.es (corresponding author).
} 
into seventeen autonomous communities (ACs). Each $\mathrm{AC}$ has political and financial autonomy, with its own government, statute and legislative bodies. They operate under a regime of functional decentralisation, each with their own administrative structures organised into ministries or departments. The ACs have a series of competences that empower them to carry out a range of legislative and administrative actions independently of the State. In this paper, we will focus on the specific competences in the field of culture in the Autonomous Community of Andalusia.

Located in the south of the Iberian Peninsula, Andalusia is the most populous autonomous community in Spain and the second largest in terms of territory. Its statute of autonomy passed in 1980 vests the executive power in the Andalusian Autonomous Government, the legislative power in the Parliament of Andalusia and the judicial power in the High Court of Justice of Andalusia. The Andalusian Autonomous Government is structured into different ministries, secretariats and directorates-general devoted to the different areas of competence. Budget allocations are also established for the different ministries depending on their needs. There are currently 11 ministries, including the Andalusian Ministry of Culture and Historical Heritage. Although its name has undergone changes over the years, it has always included among its aims the promotion, fostering, protection and dissemination of culture in all its forms and expressions. On occasions, part of the ministerial budget has been assigned to cultural research activities in pursuit of these aims.

Between 1988 and 2009, the Ministry of Culture of the Andalusian Autonomous Government made a total of 20 calls for proposals to support ethnological research through the Directorate-General for Cultural Assets. Under these so-called 'Ethnological Campaigns', 274 financial grants were awarded to a total of 151 researchers with a overall disbursement of 1.8 million nominal euros, equivalent to just under 3 million real euros in 2016. These grants, which at the time were exceptional in the Spanish context, marked the path for ethnological research in Andalusia. As well as allowing a large number of researchers to undertake their activity, they also contributed to the consolidation of Social Anthropology studies in Andalusia and its institutionalisation as an academic discipline. In addition, they were also unique in the panorama of Spanish applied research in that they established a parallelism between archaeological and ethnological activities, an approach that was not adopted in other Autonomous Communities when they assumed administrative competences in the field of culture.

In this paper, firstly we will describe the general regulatory and jurisdictional framework for the protection and safeguarding of cultural heritage in Spain as a whole and in Andalusia. We will then describe the different calls for grants for ethnological research promoted by the Andalusian Autonomous Government, contextualising them within the framework of the regulatory and budgetary evolution of the Andalusian public administration. Finally, we will analyse the impact these grants have had on the professional development of the teaching staff in the area of knowledge of Social Anthropology in Andalusia, outlining their marginal effects and differentiating them according to gender and university size using binary choice models (Logit).

\section{THE SPANISH REGULATORY FRAMEWORK}

Ethnological heritage barely received any specific attention in Spanish legislation until the enactment of the Spanish Historical Heritage Act (Ley de Patrimonio Histórico) in 1985. In fact, the Spanish Law of 13 May 1933 on the defence, conservation and enhancement of National Historical and Artistic Heritage solely embraced tangible assets of artistic, 
archaeological, palaeontological or historical interest, without any reference whever to ethnological heritage. Despite this, there were some earlier references to ethnological heritage in the Spanish legal system. For example, the Decree of 12 June 1953 mentions assets of ethnographic or folkloric interest among those to be included in the Inventory of National Artistic Treasures, with the requirement that they must be no less than a century old, thereby combining it with a historical-artistic criterion. The institutionalisation of ethnological heritage under the state legal system was carried out through its gradual incorporation under different decrees and orders: Decree 2415/1961 of 16 November establishing the Central Institute for the Restoration and Conservation of Artistic, Archaeological and Ethnological Works and Objects; the Decree of 22 September 1961 creating the National Centre for Artistic, Archaeological and Ethnological Information; Decree 3963/1964 of 3 December on the structuring of the National Artistic, Archaeological and Ethnological Information Service (Lizarazu de Mesa, 1996); and in the midst of the transition following the creation of the Andalusian Ministry of Culture, the establishment of the competences of the DirectorateGeneral for Artistic Heritage, Archives and Museums through Royal Decree 2258/1977 of 27 August, although all these actions were included under the broad umbrella of Historical and Artistic Heritage ${ }^{1}$.

The Spanish Constitution of 1978 stands out due to the special treatment given firstly to culture and secondly to historical heritage, to the extent that some authors have called it a true "Cultural Constitution", a new development in the Spanish legal system. The Preamble itself mentions the human rights, cultures and traditions, languages and institutions of the "peoples of Spain', with express recognition of the existing cultural diversity. In terms of cultural heritage, the Constitution enshrines respect for the different language modalities of Spain ${ }^{3}$, while in Article 46 it broadens the traditional concept of 'historical and artistic' heritage to also include 'cultural heritage' ${ }^{4}$, which according to Becerra García in relation to intangible assets "extends beyond the concept of monuments as a singular object valued in artistic terms to integrate it within the broader modern conception of culture" (Becerra Garcia, 1999, p. 17). Later on, Article 148 specifies the competences that may be assumed by the ACs, with sections 14, 15, 16 and 17 referring to handicrafts, museums, 'monumental heritage' and the promotion of culture and research. These functions may be assumed by the ACs without prejudice to the exclusive competences of the State laid down in Article $149^{5}$.

As can be seen, the Spanish Constitution pays special attention to culture in general and to cultural diversity in particular, although the latter is mainly focused on language modalities, thereby establishing the basis for the 'official languages' of the Spanish State. However, the treatment of Cultural Heritage is mainly from a traditional and generalised historical, artistic and monumental perspective, with only subtle references to ideas that could be interpreted as referring to ethnological, ethnographic and intangible heritage (indeed, references appear for different reasons and purposes, for example in the case of language modalities, traditions and handicrafts).

However, for our current analysis of public investment in heritage research, it should be highlighted that the text of the Constitution states that the "promotion of culture and research" is one of the exclusive competences of the ACs.

On the other hand, during this period when democracy was being forged in Spain and the Constitution was being drafted, there were also already references to ethnological heritage in the ministerial organisational chart. The National Centre for Artistic, Archaeological and Ethnological Information, created by the Ministry of National Education in $1961^{6}$, had the fundamental mission of drawing up the inventory of the nation's artistic, archaeological and 
ethnological heritage. In July 1977, this Centre was separated from the Ministry of Education and was incorporated under the aegis of the Ministry of Culture ${ }^{7}$ as a department of the Directorate-General for Artistic Heritage, Archives and Museums. Only a month later, Royal Decree 2258/1977 of 27 August on the organisational structure and functions of the Ministry of Culture was published, with section 4 stating that the Directorate-General for Artistic Heritage, Archives and Museums "shall exercise the functions of management, protection, inventory, restoration, enhancement and dissemination of historical, artistic, archaeological, palaeontological and ethnological heritage."

However, no specific unit was created within this Directorate-General for ethnological heritage, as was done for other types and areas of heritage such as the Subdirectorate-General for Artistic Heritage, the Higher Council of Fine Arts, the Subdirectorate-General for Archaeology, the Subdirectorate-General for Archives and the Subdirectorate-General for Museums, among others. In 1979, the organisational rank of the Head Office of the National Centre for Artistic, Archaeological and Ethnological Information was established ${ }^{8}$.

When Royal Decree 1601/1980 of 18 July approved a new organisational structure for the Ministry of Culture, references to 'ethnology' were once again included among the competences of the Directorate-General for Artistic Heritage, Archives and Museums, upon identical terms to those of Royal Decree 2258/1977. Shortly afterwards in 1981 the organisational structure of the Ministry of Culture was modified ${ }^{9}$, once again attributing to this Directorate-General the functions of "management, protection, inventory, restoration, enhancement and dissemination of historical, artistic, archaeological, palaeontological and ethnological heritage", but also introducing the concept of ethnological heritage by changing the Subdirectorate-General for Archaeology created by Royal Decree 1601/1980 and renaming it the "Subdirectorate-General for Archaeology and Ethnology".

However, one of the fundamental milestones in the incorporation of ethnological heritage in the state legal-administrative system was the creation of a Higher Board of Ethnology by virtue of the Order of 11 September 1981 (Official State Gazette (BOE) No. 231, 26 September 1981) under the aegis of the aforementioned Directorate-General for Artistic Heritage, Archives and Museums through the Subdirectorate-General for Archaeology and Ethnology. This Order regulates the composition of the Higher Board of Ethnology as a consultative body consisting of "seven members, who must be full academicians of the Royal Academies of History or Fine Arts, or university lecturers for subjects related with ethnology, or museum curators or persons with relevant competence in ethnological matters" (section 3). Its functions are also detailed in section $5^{10}$. This model, as will be seen, was largely adopted by the Andalusian Administration following the transfer of its competences.

Law 13/1985 of 25 June on Spanish Historical Heritage (Ley 13/1985, de 25 de junio, del Patrimonio Histórico Español), which repealed and replaced the legislation dating from the Second Spanish Republic, incorporated ethnographic heritage for the first time, devoting a specific section to this area. In fact, in its preamble it clearly anticipated this change by highlighting the inclusion of a new definition of Historical Heritage which "includes both movable and immovable assets, Archaeological and Ethnographic Heritage, Museums, Archives and Libraries owned by the State and Documentary and Bibliographical Heritage". However, the treatment of ethnographic heritage in Part VI of the Law is very brief, consisting of only two sections. The first of these provides a definition of the assets that make up ethnographic heritage (section 46), distinguishing between immovable and movable assets 
and also including "knowledge and activities", equivalent to what is currently understood as 'intangible heritage'. The first two paragraphs of section 47 merely refer to the corresponding Parts of the Law establishing the regime for protection of immovable heritage (Parts II and IV) and movable heritage (Parts III and IV).

However, it does introduce a relevant new development for the purposes of this study in the third paragraph when it considers that "knowledge or activities deriving from traditional models or techniques used by a certain community have ethnographic value and shall enjoy administrative protection" (Agudo Torrico, 1997). It also establishes an obligation on the part of the "competent Administration" to adopt study and documentation measures when such heritage is "in foreseeable danger of disappearing." In the case in question, the competent administration is the Autonomous Community of Andalusia, which at the time was still in the process of laying its foundations and defining its configuration.

\section{FRAMEWORK OF COMPETENCES AND ORGANISATIONAL STRUCTURE OF THE AUTONOMOUS COMMUNITY OF ANDALUSIA}

The Ministry of Culture of the Andalusian Autonomous Government was created at the same time as the founding of the government itself, as published in the minutes of the session for the reconstitution of the Andalusian Autonomous Government and appointment of the Permanent Council and the Regional Ministers (Official Gazette of the Andalusian Autonomous Government (BOJA) No. 2 of 11/9/1979), although the regulatory development of its structure and competences was not carried until nearly a year later (Decree 14/1980 of 14 July). These first regulations established a provisional structure given that its definitive powers were "far from being completely fixed", consisting of two Directorates-General: the Directorate-General for Cultural Promotion and the Directorate-General for Youth and Sport. However, the functions of the former were simply stated as being the direction and management of the corresponding services and "to resolve matters of the Ministry that fall within its competence" (section 4).

The first transfers of competences to the Autonomous Community of Andalusia under Royal Decree 1075/1981 of 24 April were limited to aspects relating to protection of bibliographical heritage, intellectual property and the legal deposit of books and other publications. Shortly afterwards, the organisational structure of the Regional Ministry of Culture was modified with the creation of the Directorate-General for Cultural Heritage, although without detailing any specific functions (Decree 71/1981). This was logical, given that the Statute of Autonomy had not been passed at that stage and the most relevant competences in the area of Culture had still not been transferred ${ }^{11}$. This organisational structure was maintained in Decree 46/1982, which was also of a provisional nature "pending compliance with the terms of section 36 of the Statute of Autonomy" and did not add any further changes or specification of the functions of each Directorate-General (Pérez Yruela \& Vives, 2012). However, its regulations passed by Decree 130/1982 of 13 October established a structure that was to be maintained "until the transfer of competences". The DirectorateGeneral for Cultural Heritage was attributed the function of overseeing "the conservation, defence, protection and enrichment of the Cultural Heritage of Andalusia" and was structured into three differentiated services: the Historical-Artistic, Archaeological and Ethnological Heritage Service, the Libraries Service, and the Archives and Museums Service ${ }^{12}$. 
The consolidation of the paradigm changes in Andalusia began following the enactment of the Statute of Autonomy by virtue of Organic Law 6/1981 of 30 December, which already introduced references to what is understand today as ethnological heritage. For example, it includes references to participation by all citizens in "political, economic, cultural and social life" (section 12(1)) and the obligation of the public authorities to guarantee "access by all Andalusians to the educational and cultural levels that allow them to achieve their personal and social fulfilment" and to "strengthen the awareness of Andalusian identity through research, dissemination and knowledge of the historical, cultural and linguistic values of the Andalusian people in all their wealth and variety" (section12(2)). Furthermore, section 13 establishes the list of competences considered by the Andalusian Parliament to be exclusive to the Autonomous Community, including "promotion and fostering of culture in all its forms and expressions" (section 13(26)) and "historical, artistic, monumental, archaeological and scientific heritage" (section 13(27)). When the competences in the field of culture were transferred by Royal Decree 864/1984 of 29 February, this paradigm shift introduced by the Constitution and gradually being adopted by the State Administration was then transferred to the sphere of the Autonomous Community. Thus, section 1 of Annex I of this Royal Decree establishes the transfer of "all functions relating to historical, artistic, monumental, architectural, archaeological, palaeontological and ethnological heritage and to bibliographical and documentary treasures", with the exceptions set out in Article 149 of the Spanish Constitution. However, the passing of this Royal Decree was only the final result of a negotiation process between the State and the Andalusian Autonomous Government and the framework of competences agreed had been known for months beforehand. Accordingly, the General Budget of the Andalusian Autonomous Community for 1984 had already incorporated the necessary items to address the new functions assumed by the Andalusian Autonomous Government, including the functions of research, promotion and dissemination of ethnological heritage ${ }^{13}$.

Following the transfer of competences, the Ministry of Culture of the Andalusian Autonomous Government was restructured by virtue of Decree 26/1984 of 8 February. This Decree increased the number of Directorates-General, adding the Directorate-General for Cultural Research to the existing ones (the Directorate-General for Cultural Heritage, the Directorate-General for Cultural Promotion and the Directorate-General for Youth and Sports) and attributing it the function of "research and study of the cultural characteristics of the Andalusian people in its various linguistic, historical, artistic and anthropological aspects, as well as the dissemination of the results obtained with the aim of contributing to foster awareness of Andalusian identity; management and execution of the administrative decisions of the competent bodies of the Andalusian Cultural Institute" (section 8). Meanwhile, the previously existing Directorate-General for Cultural Heritage was assigned the function of "inventory, defence and conservation of historical, artistic, monumental, archaeological, palaeontological, documentary and bibliographical heritage; technical support, coordination and inspection of all archives and museums and management of the archives and museums under the responsibility of the Autonomous Community" (section 7). However, this structure was barely given time to establish itself given that following the transfer of competences at the end of February the Regional Ministry had to be restructured again, with a new administrative structure and distribution of functions being laid down by Decree 66/1984 of 27 March. Four Directorates-General were established: the Directorate-General for Fine Arts, the Directorate-General for Books, Libraries and Archives, the Directorate-General for 
Theatre, Music and Cinematography and the Directorate-General for Youth and Sport. The functions of the former, which was responsible for ethnographic matters, were the "inventory, defence and conservation of Historical Heritage", as well as competences over museums and research and promotion of visual arts. This was seemingly a step backwards in the administrative relevance of ethnological heritage management. Yet this was not the case, with the reason behind this change being to adapt to the structure that the Spanish Ministry of Culture had adopted.

The 1984 budget, which was somewhat complex to prepare due to the transfer of competences, was not approved by the Andalusian Parliament until June of the year in which it was to be implemented. In general terms, the budget of the Andalusian Autonomous Government increased by $392 \%$ compared to 1983, with the Regional Ministry of Culture being one of the main beneficiaries, increasing from 449 million pesetas in 1983 to 6.777 billion pesetas in 1984. Under this budget, two different items corresponding to the Regional Ministry of Culture relating to ethnological heritage research were included in the real investments annex: firstly, in budget entry 621 there was an item consisting of 73.3 million pesetas for "Prospection, excavation, research and evaluation of Archaeological and Ethnological Heritage", and secondly an item consisting of 100 million pesetas for an "Archaeological and Ethnological Heritage Programme"14.

Shortly afterwards and following in the wake of the Spanish Ministry of Culture, by virtue of Decree 248/1984 of 25 September the Regional Ministry of Culture created the Andalusian Fine Arts Committees, including the Andalusian Ethnology Committee, whose functions as established in the Decree are: "to act as a body providing information, consultation and advice to the Directorate-General for Fine Arts"; "to propose to the Directorate-General for Fine Arts any measures it deems appropriate to ensure the conservation of Ethnological Heritage in the Andalusian Autonomous Community"; "to submit to the Directorate-General for Fine Arts any suggestions it deems appropriate for the conservation and improvement of Ethnological Heritage"; "to issue reports on any regulations it plans to issue for the protection, defence and research of Historical and Artistic Heritage of an ethnological nature"; "to report on the annual plan for ethnological research and prospections" (thus providing for the implementation of a specific annual plan); and finally, "to act as the Editorial Board of the Fine Arts-Ethnological Heritage Yearbook".

The first term of office of the Andalusian Autonomous Government consisted of two distinct periods, given that its President, Rafael Escuredo Fernández, resigned on 8 March 1984 and was replaced by then Vice-President José Rodríguez de la Borbolla, who appointed a new Government Council (Decree 42/1984) which included Javier Torres Vela as Regional Minister of Culture. In January 1985, Javier Torres Vela restructured the Regional Ministry by incorporating new directorates-general: the Directorate-General for Fine Arts, the Directorate-General for Books, Libraries and Archives, the Directorate-General for Theatre, Music and Cinematography and the Directorate-General for Youth and Sports. The Directorate-General for Fine Arts was tasked with "the inventory, defence and conservation of Historical-Artistic Heritage; technical support, coordination, management and inspection of the Museums under the Autonomous Community's responsibility and research, promotion and dissemination of Visual Arts", with a structure consisting of two different units: the Artistic Heritage Service and the Museums and Visual Arts Service ${ }^{15}$. Shortly afterwards, the Order of 7 February 1985 established the internal organisation of the different services of the 
Regional Ministry, incorporating the Archaeological and Ethnographic Heritage Section into the aforementioned Artistic Heritage Service.

The Regional Ministry of Culture was restructured once again following the regional elections of 1986, being replaced by a new organisation composed of the following directorates-general: The Directorate-General for Cultural Assets, the Directorate-General for Cultural Development and Promotion, the Directorate-General for Youth and the DirectorateGeneral for Sports. The first of these assumed "the competences of the former DirectorateGeneral for Fine Arts and those relating to Bibliographical and Documentary Heritage, as well as Archives, which were previously under the responsibility of the Directorate-General for Books, Libraries and Archives"16. This organisation of the structure and the different competences remained practically unchanged during the following three terms of office, except for the broadening of the scope of the Directorate-General for Youth to incorporate matters relating to promotion and management of volunteering ${ }^{17}$. Two years later, regulations were passed to further define the competences of the different directorates-general. The Directorate-General for Cultural Assets was charged with "supervision, enhancement and promotion of the Historical Heritage of Andalusia, exercising the functions of research, protection, conservation, restoration and dissemination" and, in particular, "protection and conservation of Archaeological and Ethnographic Heritage", along with the tasks of research into historical and artistic heritage ${ }^{18}$. The last modification of the structure of the Regional Ministry of Culture during the period under analysis was established by Decree 486/2004 of 14 September, which maintained the Directorate-General for Cultural Assets in the organisational structure of the Regional Ministry of Culture. This Decree defines the competences of the Regional Ministry of Culture, including "promotion and fostering of culture in manifestations and expressions such as historical, artistic, monumental, archaeological, ethnological, bibliographical and documentary heritage."

Therefore, in the period between 1984 and 2009 during which the ethnological research grants considered in this study were announced, the calls for proposals and the corresponding resolutions were the responsibility of the Directorate-General for Fine Arts between 1984 and 1986, after which they were assumed by the Directorate-General for Cultural Assets until the last of the calls for proposals made.

\section{FUNDING FOR ETHNOLOGICAL RESEARCH IN ANDALUSIA (1988-2009)}

As already mentioned, the General Budget of the Andalusian Autonomous Community for 1984 prepared following the transfer of its main competences incorporated specific budget allocations for ethnological research for the first time. By virtue of Royal Decree 864/1984 of 29 February, the Andalusian Autonomous Government had assumed, among many others, all the functions regarding ethnological heritage, including research promotion. Before the transfer, these functions were carried out at a national level by the Directorate-General for Fine Arts of the Spanish Ministry of Culture, which was responsible for "the functions of management, protection, inventory, restoration and enhancement and diffusion of ethnological ... heritage" through the Subdirectorate-General for Archaeology and Ethnology ${ }^{19}$. This definition of the functions of the Spanish Ministry's Directorate-General therefore helps to clarify the competences transferred to Andalusia. Furthermore, a few months later the Spanish Ministry of Culture constituted the Higher Board of Ethnology, whose functions, as seen previously, included "proposing to the Director-General for Fine 
Arts the annual programme of ethnological prospections and research deemed appropriate for the State to carry out, establishing an order of priorities for their implementation" 20 .

Once these responsibilities had been assumed, two specific items linked to ethnological research were included by the Regional Ministry of Culture (through the Directorate-General for Fine Arts) in the Draft General Budget for the Andalusian Autonomous Community presented before the Andalusian Parliament by the Government Council on 6 June. These items were incorporated in Budget Entry 21.01.621: one included in section 21.B.122 called "Archaeological and Ethnological Heritage Programme" allocated 100 million pesetas, and a second item included in section 21.B.123 entitled "Prospection, excavation, research and evaluation of Archaeological and Ethnological Heritage", allocated 73.3 million pesetas. However, one may ask how this line of support for research in this area arose, which had no parallel in other Spanish regions or in Spain as a whole. Its inclusion was the result of the investments contemplated in the 'Economic Plan for Andalusia 1984-1986' (PEA). This strategic planning document made express reference to Cultural Heritage, highlighting that despite its wealth and importance "the outlook is not very encouraging here either", not only because of the poor state of this architectural and archaeological heritage which was "in need of major investments", but also because of "the total neglect of ethnographic heritage", in view of which it was considered that "significant and urgent lines of action" were necessary ${ }^{21}$. Indeed, this strategic document envisaged allocation of a total of $1,326,800,000$ pesetas to Cultural Heritage, of which 268 million pesetas were investments to be funded by the Andalusian Autonomous Government and the rest from funding received for transferred or assumed competences and services, as well as a total investment of 1.940 billion pesetas per year for the following two financial years ${ }^{22}$. Highlights among the Cultural Heritage measures incorporated in the PEA include C.6: Organisation of training and advanced training courses for cultural heritage technicians and award of scholarships and grants for research; C.7: Inventories and cataloguing of architectural, archaeological and ethnographic heritage; C.8: Acquisitions and expropriations of monuments and archaeological and ethnographic heritage; and finally, C.10: Archaeological and ethnographic research programme. In fact, in the end the amount contemplated for "Actions relating to archaeological and ethnographic heritage" was 173.3 million pesetas for 1984, without establishing any subsequent commitments for 1985 and $1986^{23}$. Accordingly, the aforementioned amounts were incorporated into the 1984 budget and the Andalusian Ethnology Committee was created as an advisory body of the Directorate-General for Fine Arts.

However, despite their incorporation in the budget, in reality the result was disappointing. At the end of the 1984 financial year, two questions were posed in the Andalusian Parliament asking about the degree of execution of both these items ${ }^{24}$. The responses were slow in coming and not very positive for ethnological research: the only thing that had been done was a call for grants for the 1984 Archaeological Campaign by virtue of the Order of 28 January 1985, although the Regional Minister stated that "the ethnology programme will be set in motion at the first meeting of the Andalusian Ethnology Committee," adding that the aforementioned funding would be transferred "to the current 1985 financial year to carry out actions in the field of archaeology and ethnology, such as consolidation, restoration, payment of compensation for compulsory expropriation, publications, etc. ${ }^{25}$. But despite this reply from the Regional Minister, in reality between 1985 and 1986 no calls were made for ethnological research, nor were any new budget items 
incorporated under the budget for the Autonomous Community during those years as would have been logical in accordance with the terms of the PEA.

The situation began to change with the drafting of the Andalusian Economic Development Programme 1987-1990 (PADE), which included a specific programme within the area of Culture entitled "15.04: Archaeology and Ethnology", the responsibility for which fell to the Directorate-General for Cultural Assets, which had assumed the competences of the former Directorate-General for Fine Arts. The programme had three objectives, two of which referred to actions in zones of ethnographic interest (solely in reference to historic sites) and the dissemination of Andalusian ethnographic heritage. It also indicated the budget allocation for its development, which amounted to 200 million pesetas in 1987, 250 million pesetas for 1988, 260 million pesetas for 1989 and finally 270 million pesetas for 1990 . These investments were expected to create some 3,902 jobs in each year of its duration. However, upon consideration of the actions envisaged ethnology is once again relegated to the background, given that they are limited to carrying out "surveys, prospections, excavations, studies and publications on archaeological zones and historic sites" and "emergency archaeological actions" (Junta de Andalucía, 1987, pp. 221-227).

Nonetheless, several items were incorporated in the General Budget of the Andalusian Autonomous Community for 1988 to implement the above programme. There are two different items in the Annex of Investments computed as Capital Transfers to Families and Non-Profit Institutions: entry 780.00 .3174 for systematic archaeological and ethnological activities and entry 780.01.3175 for emergency archaeological and ethnological activities, endowed with 100 and 110 million pesetas respectively. This represented almost 3\% of the budget of the Regional Ministry, somewhat less than what was established in the PADE yet higher than what was actually executed, given that curiously during that year, without publication of any call for proposals or express resolution in the Official Gazette of the Andalusian Autonomous Government (BOJA), 21 grants were awarded for ethnological research projects totalling $16,545,850$ pesetas $^{26}$.

In April 1989, the draft General Plan for Cultural Assets 1989-1994 was submitted to the Andalusian Parliament, which following its debate was approved in the session of 21 June 1989. This Plan envisaged four fields (Ethnology, Archaeology, Movable Assets and Immovable Assets) in which action was to be taken along five main lines (Research, Restoration, Conservation, Protection and Dissemination). The Plan includes a specific Ethnology Research Plan and a brief diagnosis of the situation of ethnology in Andalusia, which could almost be interpreted as a diagnosis of the Area of Knowledge of Social Anthropology in Andalusia and, more specifically, in Seville. Its conclusions are limited to the state of university studies, the situation of the two existing journals (Jiménez De Madariaga \& Checa Olmos, 2012), the absence of museums or collections and the lack of an adequate framework for theoretical debate among Andalusian anthropologists. The text of the introductory diagnosis of the programme incorporated in the Plan coincided in general terms with a work published some years later by the President of the Andalusian Ethnology Committee in the first Andalusian Ethnological Yearbook published to summarise the projects financed by the grants (Moreno Navarro, 1991). The fundamental objectives of the Ethnological Research Plan were, on the one hand, "to raise the level of Andalusian anthropology through continuous training of ethnologists and support for research programmes and, on the other hand, to create instruments that allow the recovery and dissemination of Andalusia's ethnological heritage." Among other matters, the programme 
proposed two actions that were included in subsequent calls: "Development of research programmes aimed at deepening Andalusian anthropology itself, preferably dealing with: kinship, tales and legends, festivals, games, popular religious manifestations, territorial tensions, ethnic minorities, etc."; and "Organisation of seminars and courses aimed at anthropology professionals and, more specifically, a biennial international symposium on the subject."

The Order of 22 May 1989 regulated the award of grants for ethnographic activities and the terms of the calls for proposals. The fundamental objective was to achieve a better degree of knowledge of ethnological heritage, i.e. "the movable and immovable assets and the knowledge and activities that are or have been a relevant expression of the traditional culture of the Spanish people in its material, social or spiritual aspects"27, with promotion of research activity being considered of particular importance. The calls were aimed at researchers in the field of Ethnography or Social Anthropology, whether individually or as members of an ethnographic research team, Departments or Institutes of Spanish Universities with competences in the field of Ethnography, and finally, Institutes of the Higher Council for Scientific Research (CSIC). The purpose of the activities to be financed needed to be within the scope of the following areas: (a) Systematic Ethnographic Research, consisting of the collection and ordering of data and in-depth analysis of a specific cultural phenomenon; (b) Ethnographic Prospection, consisting of a sample or initial approach to a specific cultural phenomenon; (c) Ethnographic documentation work using planimetrics, photography or any other audiovisual medium; (d) Study of ethnographic materials deposited in the Museums of the Autonomous Community and of the Documentary Heritage of ethnographic interest existing in its Archives. Upon completion of the activity, the beneficiaries were required to submit a final scientific report, which was published in a series by the Regional Ministry of Culture. The transfer of publication rights was understood to be exclusive and free of charge. In addition, acceptance of the grant implied the obligation to participate in an Andalusian Ethnography Conference organised by the Directorate-General, where each researcher presented the progress or results of their work. This Order served as the regulatory framework for the successive annual calls for proposals during the period from 1989 to 1992 and the corresponding resolutions.

In 1993, a new consolidated text was drafted for calls (Order of 14 January 1993). However, the only change made was the procedure for processing and justification of the financing received, with the rest of the regulation remaining essentially unchanged until 2002. The 1998 call defined specific objectives for the grants: "Protection and dissemination of Ethnological Heritage in protected natural areas of Andalusia, traditional economic activities: current projection and proposals for protection, communal property today and the anthropology of fishing, techniques and society." This practice of including specific priority objectives was maintained in the following calls. In the 1999 campaign, priority was given to research projects that included "interdisciplinary proposals for the protection, conservation and promotion of ethnological heritage"; for the 2002-2007 campaigns, priority was given to the following areas: "a) Systematic ethnographic research, consisting of the collection and ordering of data and in-depth analysis of a cultural phenomenon; b) Ethnographic prospection, consisting of a sample or initial approach to a cultural phenomenon; c) Ethnographic documentation work using planimetrics, photography or any other audiovisual medium; d) Study of ethnographic materials deposited in the museums of the Autonomous Community and of the documentary heritage of ethnographic interest existing in its archives." Finally, for 
the last campaign in 2009, priority was given to "studies of intangible heritage and its relationships in Andalusia, studies of activities of ethnological interest where the gender perspective is taken into account and studies aimed at drawing up municipal, regional or thematic ethnographic charts."

The application process for the grants for ethnographic activities was also defined in the Order of 22 May 1989 28 . Apart from the forms, identification data and curriculum vitae (stating the "academic qualifications and experience in ethnographic work"), the candidates were required to submit a report on the activity to be carried out and a project "specifying the background, objectives, methodology, phases and activities", as well as a detailed budget. Although it is the Director-General of Cultural Assets who proposes to the Regional Minister of Culture the award or refusal of the grants requested, section 5 of the above Order provides that this must be done "in view of the report of the Andalusian Ethnology Committee", and section 5(2) goes on to state that "applications will be reported by the Andalusian Ethnology Committee before 31 January of each year." As can be seen, the Andalusian Ethnology Committee played a fundamental role in the whole procedure of public funding for ethnographic research in Andalusia.

In 1987, the first Andalusian Ethnology Committee was appointed ${ }^{29}$, consisting of nine members (as prescribed by law): eight members and a chairperson, all of whom have voting rights. The Chairperson of the first Committee was Isidoro Moreno Navarro, who at the time was a Professor of Social Anthropology - the first in Andalusia - at the University of Seville. Eight further appointments were made, with no fixed term and without any new appointment since the last appointment in 2011. Isidoro Moreno Navarro was Chairperson of the Committee from 1987 to 1992. He was followed by José Antonio González Alcantud, Professor of Social Anthropology at the University of Granada (1997-2003). Esther Fernández de Paz, Professor of Social Anthropology at the University of Seville, was appointed next in 2005. Finally, the last Committee was presided over by Juan Agudo Torrico, Professor of Social Anthropology at the University of Seville.

Between 1988 and 2009, twenty calls for grants for ethnographic activities were made, mainly coinciding with the appointments to the Ethnology Committee except for the last appointment in 2011. One of the tasks assigned to the Committee was precisely to report on the applications for grants received by the Directorate-General for Cultural Assets. This involved reviewing the reports and projects submitted and making consensual decisions on the viability and interest of each case in order to finally submit a proposal to the Director-General - and ultimately to the Regional Minister - regarding the possible candidates for the grants. The profile of the members of the Committee is considered fundamental to carry out its decision-making functions, particularly in the event of possible doubts, which is why most of them were anthropologists. The repetition of its members in the early years has a clear explanation.

At the end of the 1980s, Social Anthropology was in the process of being established as an academic discipline in Andalusian universities. There were still few university lecturers devoted to this area of knowledge and also few professionals working as such in museums, research centres and other institutions (Aguilar Criado, 1992; Moreno Navarro, 1973). Some of the members of the Committee were renewed as the number of anthropologists majoring in the area and holding a Bachelor's Degree in Social Anthropology increased, and a specific line of research and professionalisation in the field of ethnological heritage gradually emerged. As will be seen later, these grants for ethnographic research were undoubtedly decisive for the consolidation of Social Anthropology in Andalusia. 
As previously mentioned, the obligations of the beneficiaries of the grants included the presentation of a Scientific Report (within two or three years, depending on the Call); participation at the Andalusian Ethnology Conferences which were held annually (in the early years at least) where each researcher had to present the progress or results of their work; and finally submission of the report for publication, which was done through the so-called 'Andalusian Ethnological Yearbooks' (Junta de Andalucía, 1991, 1992, 1994, 1996, 1999, 2000, 2002, 2006).

A review of the topics of the research projects funded shows that, while in some years there was a great deal of diversity in the topics covered, in other years they were grouped into themes. This can be seen in the content of some of the Ethnological Yearbooks, which group the projects presented by the researchers in different sections. For example, in the 1991 Yearbook the reports are distributed as follows: 'Economic changes and socio-cultural transformations', 'Beliefs, symbols and rituals', 'Work, gender, identities', 'Practices, techniques and ways of life', and 'Group and social relations'. The 1992-93 Yearbook is also grouped into sections. They are similar to those of 1991, with the addition of 'Territoriality, communication systems and identity' and 'Ethnic minorities'. Apart from being a simple strategy to coherently organise the presentation of the reports, it also indicates the lines of research that were prioritised in Andalusia during those years. Some calls for proposals specifically indicate preferential lines of research for the award of grants. For example, the 1997 Call for Proposals stated that "the following lines of research will be given preference: Protection and dissemination of Ethnological Heritage in protected natural areas of Andalusia, Traditional economic activities: Current projection and proposals for protection, Communal property today, and Anthropology of fishing, technique and society." Regardless of the fact that the Directorate-General for Cultural Assets and the Regional Ministry of Culture had their own preferred lines of action as published in the different strategic plans, it was the members of the Ethnology Committee themselves who, whether intentionally or not, made decisions on the award of research funding based on topics of interest that arose within the anthropological discipline itself and which attracted the attention of the majority of the candidates who proposed projects. A diachronic analysis of these topics offers an insight into the historical trajectory of anthropology in Andalusia.

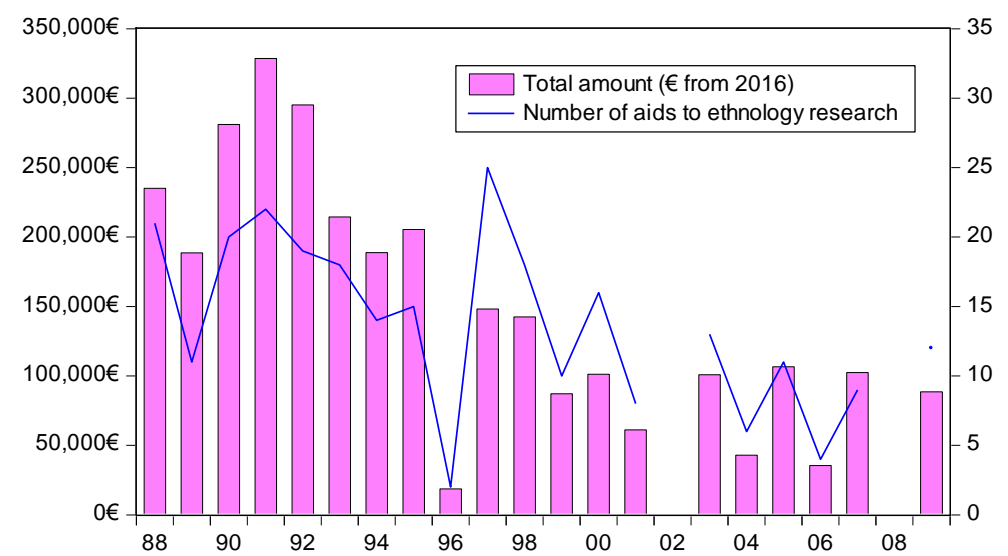

Figure no. 1 - Evolution of the number of grants and the overall amount approved in each Ethnological Campaign (1988-2009) 
The repetition of projects with the same names or with parallel themes that complement each other is justified by the fact that many projects constituted the basis for doctoral theses carried out over at least three years. The procedure to continue with a new grant and, therefore, with the project - which could have a duration of up to three years - was carried out annually through the submission of a report and presentation of the progress or partial results at the Ethnology Conference ${ }^{30}$. A total of 17 Andalusian Ethnology Conferences were held, initially one in each capital of the Andalusian provinces (starting with Seville), later in the towns of Úbeda, Ronda, Puerto de Santa María, Vélez-Blanco and Vélez Rubio, Aracena and Carmona, and finally once again in Seville, Granada and Malaga. At these conferences, the beneficiaries of the grants had to attend and present their work as one of the commitments established in the terms and conditions of the calls for proposals (progress and/or partial or final results). Their attendance was financed by the Regional Ministry of Culture itself under the budget allocated to the Ethnological Activity Campaigns. The presence of the members of the Ethnology Committee (not necessarily all of them) was essential to verify, through the interventions of the beneficiaries, whether the project had been carried out properly and upon the terms proposed. This was extremely important, especially for projects requiring continuity (e.g. those constituting the basis for doctoral theses), since the application with all its requirements (forms, report, project, budget, etc.) had to be presented again for the grant of the subsequent phases. At the conferences, the members of the Committee had the opportunity to assess the work done by the candidates, giving them more and better evidence to decide on future awards, if requested. This provided economic-administrative control over not only the grants awarded, but also the content and objectives achieved through these public investments in research. The Andalusian Ethnology Conferences also featured a number of guest speakers, generally academic anthropologists specialising in various areas who opened the sessions and attended the opening and closing ceremonies.

Another of the aforementioned requirements for acceptance of grants was the submission of a scientific report for publication. The Ethnological Yearbooks were published after the Ethnology Conferences were held. To this day, they constitute a fundamental tool to trace the development of ethnological-anthropological research over this period, the interest in certain subjects, the preferred research destinations, the main protagonists and the effect all of this had on Social Anthropology in Andalusia. A total of 8 publications were released in the form of books with ISBN published by the Directorate-General for Cultural Assets, many of them integrating the reports of two Campaigns, including the contributions of the guest speakers at the corresponding conferences. In their entirety, they present the results of the grant campaigns over the period from 1988 to 2003. The costs of publishing the Yearbooks were also included in the campaign budgets.

\section{ETHNOGRAPHIC ACTIVITIES RECEIVING FUNDING: DESCRIPTIVE ANALYSIS}

As mentioned above, between 1988 and 2009 a total of 20 calls for proposals were made and 274 projects were awarded grants. In current terms, the overall amount of funding granted totalled 1.8 million euros, although in real euros $(2016=100)$ this amount was very close to 3 million euros. The average amount per approved project was 10,980 real euros, although many of these projects were awarded to the same beneficiary in successive campaigns. Each 
of the 151 different beneficiaries received an average of 1.8 grants over the period, with an average amount of 19,687 real euros.

Figure no. 1 shows the evolution of the overall amount approved in each Ethnological Campaign, as well as the number of grants awarded. The 1997 campaign is notable due to the high number of grants awarded. This was because the 1996 grants the costs of which could not be met due to budget shortfalls were also awarded in 1997. Also noteworthy is the progressive decrease in both the number of grants and the amount of funding until the programme was discontinued, an aspect we will return to later.

Table no. 1 - Typology of applicants according to qualifications attained

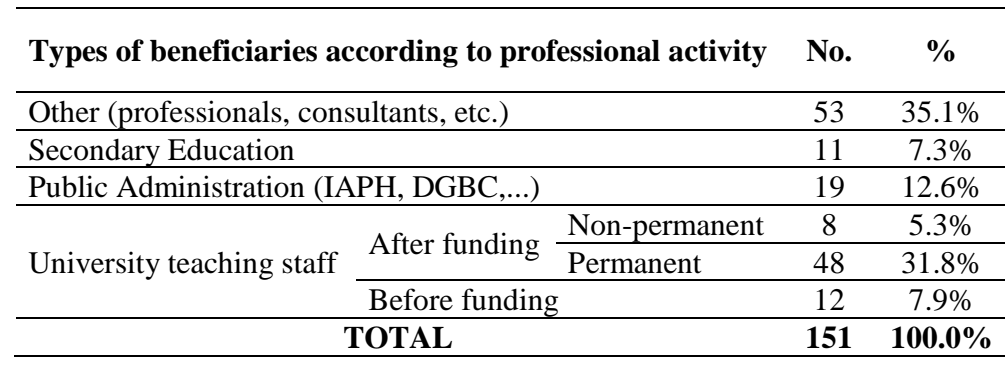

Upon analysis of the beneficiaries of the grants for ethnographic activities, two distinct groups may be distinguished: those already working as anthropologists, almost exclusively at university level, and those who at the time were mainly students of anthropology or, to a much lesser extent, of other related disciplines, many of whom continued their academic careers at different universities. In fact, $7.9 \%$ of the applicants were senior lecturers or professors at the time of applying, while $37.1 \%$ were progressively integrated into the anthropology or related areas of different departments. Another relevant group of beneficiaries (12.6\%) consists of persons who subsequently joined the Andalusian public administration responsible for this area, both in the Directorate-General for Cultural Assets (DGBC) and the Andalusian Historical Heritage Institute (IAPH). A considerable number of applicants chose to work in secondary education (7.3\%), while the remaining applicants carried out temporary ethnological consultancy work for public authorities (3.3\%) or research tasks, whether or not linked to university research groups $(9.3 \%)$.

A slightly more detailed analysis may be carried out by focusing on the impact of the grants in the context of the area of knowledge of Social Anthropology in Andalusian universities. Taking into account the current teaching staff and those who have retired over the last five years, a total of 90 lecturers have taught in Andalusian universities. Of these, 63 are permanent teaching staff, whether civil servants or on permanent contracts, while 27 are temporary or research teaching staff. Of the permanent teaching staff, $71.4 \%$ received some kind of aid or grant under the Ethnological Campaign programme, while a much smaller percentage $(11.1 \%)$ of the temporary teaching staff received such assistance. This is logical, given that this category of teaching staff consists of persons generally starting out with their academic careers who were therefore not in a position to apply for grants when the programme ended. Only in the case of associate lecturers is the percentage of persons who received grants relevant. To sum up, 58.5\% of the full-time equivalent teaching staff in the area of social anthropology received research grants under the ethnological campaigns. Perhaps a more 
relevant means of assessing the effect of these grants is to analyse the importance they had for the development of the applicants' initial research and their consolidation as researchers. Of the 274 grants awarded, 62 of them were already $\mathrm{PhD}$ holders at the time of the award, while 116 others defended their doctoral thesis afterwards. Of these, in the case of 82 of the grants, the subject matter of the projects coincided with the thesis subsequently defended, and it was therefore a means of financing their research with a view to obtaining a doctorate. In fact, of the 151 different beneficiaries over the whole period, 48 completed a doctoral thesis related to the grant they had obtained previously $(31.8 \%)$, of whom $58.3 \%$ are currently university lecturers and another $12.5 \%$ hold relevant positions in the IAPH or the DGBC. Later on, we will measure the impact of this type of support on the university careers of Andalusian teaching staff.

Having analysed the positive impact on ethnological research in Andalusia resulting from the Ethnological Campaign programme, the next step is to analyse their significance in terms of public spending in the Autonomous Community. As mentioned above, a total of 274 grants were awarded, but they were not distributed evenly over time. After reaching a peak between 1990 and 1992, the number and average amount of the grants declined in both nominal and real terms until they disappeared with the onset of the economic crisis (Figure no. 2). In fact, the amount granted between 2007 and 2009 was only $21 \%$ of the three-year period from 1990 to 1992 .

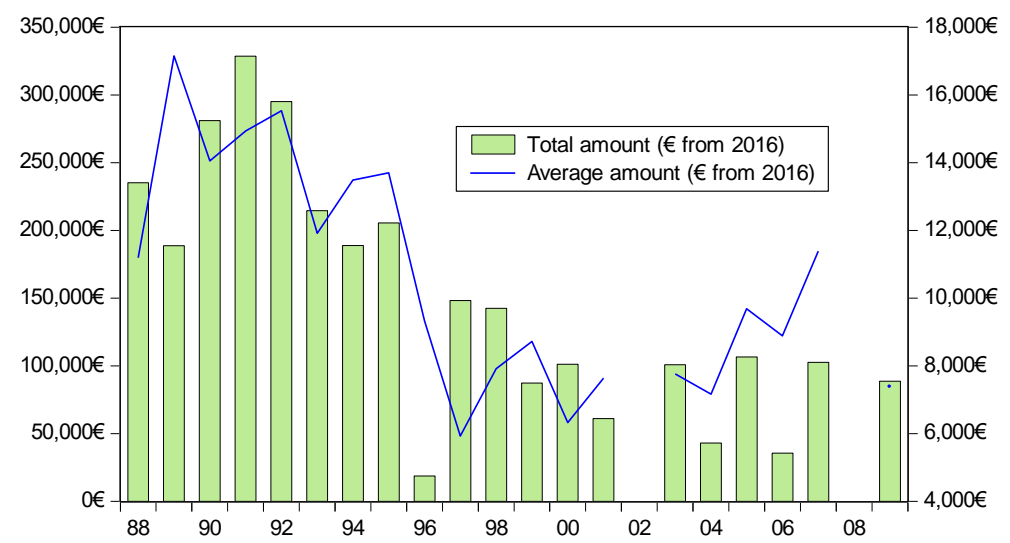

Figure no. 2 - Evolution of the total and average amount granted (real $€ 2016$ )

However, a comparison of the amount devoted to this funding with the overall budget of the Andalusian Autonomous Government reveals to an even greater extent the loss of relative importance of this programme in the Autonomous Community's public spending as a whole. Figure no. 2 shows the evolution of the overall amount allocated to funding in each campaign, as well as its relative importance in the total budget of the Andalusian Autonomous Government. In both cases, there is a progressive decline in the relative importance of the provision of this type of funding by the Andalusian Autonomous Government.

Apart from the specific decrease in this budget item, this loss of relative importance is also a direct consequence of the progressive decrease in the relative importance of spending and investment by the Regional Ministry of Culture in the context of the Andalusian Administration. In fact, there was a 50\% reduction in the relative importance of the Regional 
Ministry of Culture between the first budgets after the transfer of competences (1985-1990), during which it received $1.9 \%$ of the total, and the final years of the series (2006-2009), during which it represented $0.9 \%$.

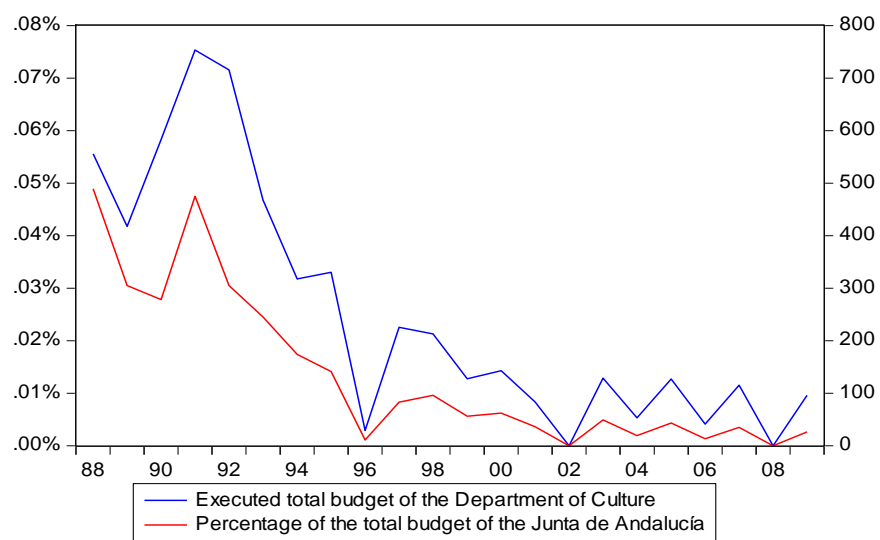

Figure no. 3 - Evolution of budget allocation and relative importance

Moreover, between 1995 and 2009 the budget of the Directorate-General for Cultural Assets, which in 1995 represented $38.3 \%$ of the total budget of the Regional Ministry, was progressively reduced to only $16.8 \%$ of the total in 2009 (Figure no. 3). At the peak of the economic and financial crisis in 2010, this programme of continuous training for ethnologists and support for research programmes which had managed to raise the level of Andalusian anthropology and facilitate the creation of instruments to allow the recovery and dissemination of Andalusian ethnological heritage was abolished.

\section{THE IMPACT OF FUNDING ON ACADEMIC CAREERS}

We will now seek to assess the impact that these grants had on the evolution of the academic careers of social anthropology teaching staff in Andalusia. It should be borne in mind that in Spanish universities the creation of the different disciplines or 'areas of knowledge' is relatively recent, arising under the regulations to develop Spanish Organic Law 11/1983 of 25 August on University Reform ("LRU") and more specifically through Royal Decree 2360/1984 of 12 December on University Departments and Royal Decree 1888/1984 of 26 September regulating competitions for posts in university teaching bodies. The annex to the latter Decree included a catalogue of areas of knowledge with the subjects linked to them in the curricula in force at the time, which included the area of Social Anthropology for lecturers teaching in the Faculties of Philosophy and Arts under the Geography and History degree courses for the subjects of Anthropology, Social Anthropology, Cultural Anthropology and Ethnology. Until then there had been no specific degrees in the field of Anthropology or Ethnology in Spanish universities, so the first lecturers in this area were either graduates of the Faculties of Geography and History or had received training abroad.

At that time, the situation in Andalusia was even worse. Only three lecturers had obtained posts via competitive examinations in previous years at the University of Seville, linked to the subject of American History under the curriculum of the Geography and History 
Division of the Faculty of Philosophy and Arts, which was established in 1976 (Jimenez Nunez, 2008). ${ }^{31}$ When the University of Seville published the curricula for the last two years (Second Cycle) of the American History section, the subject of American Cultural Anthropology was incorporated as an optional fourth-year subject. However, it was not until 1986 that the first teaching posts were offered in this recently created area of knowledge, at a time when the Departments had not even been created under the LRU ${ }^{32}$. The emergence of this area, at least from a formal viewpoint, may be traced to the introduction of the curricula of the Bachelor's Degree in Geography and History in 1983, which created the Cultural Anthropology section as a major with a total of 13 anthropology and ethnography subjects. However, the Degree was not officially recognised until $1988^{33}$ and certain subjects were also incorporated under other curricula (Social Work, Primary Teacher Training, etc.). In 1994 the curriculum of the Bachelor's Degree in Social and Cultural Anthropology was established, which constituted a fundamental milestone in the consolidation of this area of knowledge ${ }^{34}$. Meanwhile, at the University of Granada the first anthropology subjects were incorporated in the curricula of the Faculty of Philosophy and Arts in the Philosophy section ${ }^{35}$ and in the Faculty of Political Science and Sociology ${ }^{36}$, with the first Senior Lecturer position being created in 199037. The Bachelor's Degree in Social and Cultural Anthropology was established in $1999^{38}$. In the remaining Andalusian universities, which do not have specific Social Anthropology degrees, the first posts for university teaching staff (CDU) to teach in degree courses such as Social Work, Sociology, History, Education and Nursing were also created at the end of the 1990s: Almería and Huelva in 1997; Jaén in 1998; Cádiz in 2001 and Pablo de Olavide in 2003.

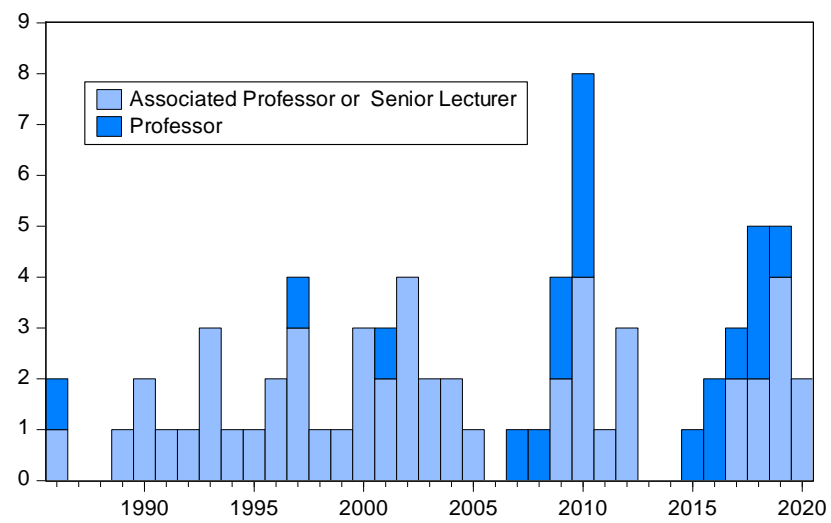

Figure no. 4 - Evolution of the number of new teaching posts

Figure no. 4 shows the evolution of the number of CDU university teaching posts - the highest level of the academic career - offered for Social Anthropology at Andalusian universities since 1986. A total of 52 publications for senior university lecturers and 20 publications for university professors have been offered, with an average annual number of slightly more than 2 posts. However, their evolution has been very volatile, a situation which may be easily explained. Until 2002, the system of competitive examinations was governed by the regulations of the LRU, with tribunals in each university consisting of five members, three of whom were appointed by drawing lots at a national level from among the teaching 
staff in the area. From 2002 to 2007, a system of prior national qualification was applied with a single national tribunal, which limited the offering of posts in universities. From 2007 onwards, a process of prior national accreditation was established with subsequent competitions in each university, which freed up the accumulated stock of teaching staff. However, due to the serious economic crisis in Spain, in 2012 the offer of new posts was limited to coverage of $10 \%$ of the posts vacated due to retirement, a further impediment that was gradually relaxed in subsequent years.

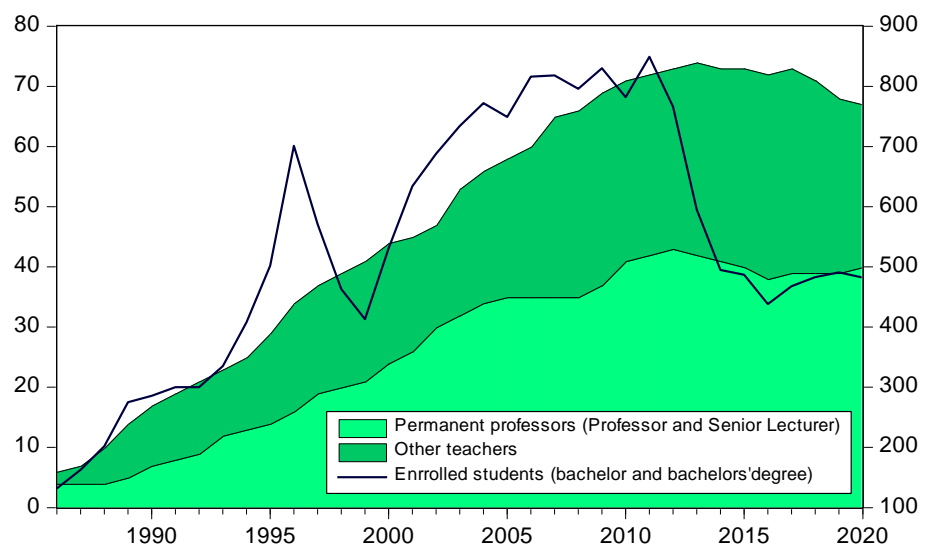

Figure no. 5 - Evolution of the teaching staff in the area of knowledge of Social Anthropology in Andalusia according to typology and number of students enrolled in degree courses

Figure no. 5 shows the evolution of full-time teaching staff in the area of knowledge of Social Anthropology in the nine public universities of Andalusia ${ }^{39}$, differentiating them by type and the number of students enrolled in Anthropology degrees ${ }^{40}$. The evolution of student numbers is characterised by a peak due to the overlapping of different curricula, as well as a decrease from the 2011-2012 academic year onwards ${ }^{41}$.

\subsection{Relevant information to consider}

In order to analyse the variables that influence the academic career of the teaching staff in this area of knowledge, a wide range of information has been obtained regarding their research activity (publications, projects, quality indicators), their initial research (doctoral theses) and their professional posts, as well as information regarding the grants received from the support programmes for ethnological research in Andalusia as described in the previous sections. The sample used consists of PhD lecturers who are working or have worked in Andalusian universities in the area of knowledge of Social Anthropology on a full-time basis between 1986 and 2020. These lecturers completed their undergraduate degrees before 2014 . Of the total number of persons included in the sample, 55 were promoted to the rank of Senior University Lecturer, while 20 reached the rank of University Professor. In this sample, the average time taken to obtain a doctorate from the time of graduation is very long (8.7 years), while the number of years taken to obtain the rank of Senior University Lecturer from the time of the doctorate is 7.9 years. Finally, it takes an average of 16.3 years from the date of obtaining the rank of Senior University Lecturer to reach the rank of University Professor 
(Figure no. 6). All the distributions are clearly asymmetric, although if we consider the time elapsed between obtaining the undergraduate degree and obtaining the rank of Senior University Lecturer, both the dispersion and the asymmetry are significantly reduced.

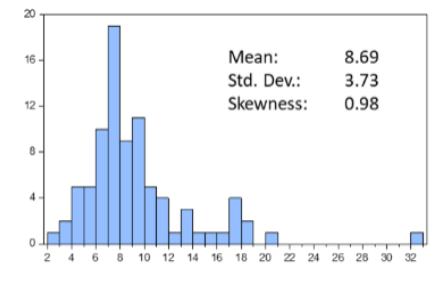

Doctorate - Bachelor Degree

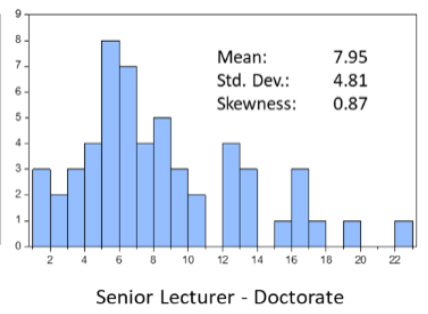

Senior Lecturer - Doctorate

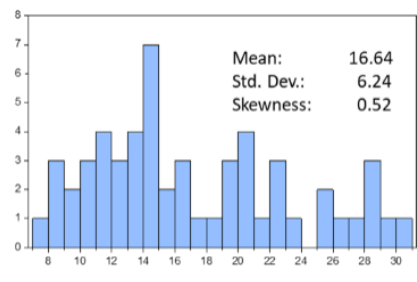

Senior Lecturer - Bachelor Degree

Figure no. 6 - Statistical distributions of the duration of the promotion process

As mentioned above, our aim is to measure the marginal effect that access to the funding in question may have had on their academic development and promotion. Access to a post as a lecturer or permanent employment is undoubtedly one of the main rewards in university careers, which are characterised by marginal differences in salaries and low mobility (SanzMenéndez, Cruz-Castro, \& Alva, 2013). Although some studies have sought to assess the influence of personal situations such as gender, marriage or parenthood (Morrison, Rudd, \& Nerad, 2011; Wolfinger, Mason, \& Goulden, 2008; Xie \& Shauman, 2003), the fact is that the variables that most often determine success in academic careers are related to academic performance and productivity (Baird, 1991; Nakhaie, 2007; Sabatier, 2010; Tien, 2007), as is logical in systems based on merit and individual competence (Allison \& Stewart, 1974; Long \& Fox, 1995). However, the quality and prestige of the institution must also be considered, as well as the lecturer's participation in research groups, due to the fact that research is increasingly a collective task. Academic inbreeding is another possible influence which, despite the usual criticisms, can also have a positive effect on the development of academic careers (Bozeman, Dietz, \& Gaughan, 2001; Neumann \& Terosky, 2007). Other factors to consider are related to mobility and research stays in prestigious centres (Aran \& Ben-David, 1968; Jonkers, 2011), although this mobility can also have negative effects on teaching staff by uprooting them from their habitual environment (Dietz \& Bozeman, 2005; Melin, 2005). Taking into account the above considerations, a database has been created for the 86 teaching staff which has been used to obtain a total of 59 different quantitative (discrete or continuous) and dichotomous (dummy) variables related to their academic career, along with those related to the funding received under the programme of Ethnological Research Grants implemented by the Andalusian Autonomous Government as described above, in order to evaluate their possible contribution to successful career promotion. A complete list of the variables used and their sources is included in the Annex. Overall, 27 variables have been considered relating to academic productivity and research quality: 17 variables relating to the progress of their academic career; 3 variables relating to the prestige and size of the institution; and 10 variables relating to the ethnological research grants considered in this paper, in addition to others relating to gender and age. The literature cited above includes many examples of applications that attempt to measure the success of academic careers using very different statistical or econometric techniques. In our case, we have opted to use qualitative response or discrete choice regression models (Kramer, 1991; Maddala, 1983), which allow measurement of the 
influence each of the explanatory variables considered may have on the probability of success, i.e. the probability of promotion to the rank of Senior University Lecturer.

\subsection{Certain formal matters}

The aim of the model is to determine whether the specific financial aid implemented by the Andalusian Autonomous Government to support ethnological research - the so-called 'Ethnological Campaigns' - had a decisive effect on the probability of reaching the rank of Senior University Lecturer (SUL). To do so, it was considered that for each individual i the dependent variable may only assume two values: 1 if SUL status is reached or 0 if it is not, all of which depends on a series of explanatory variables, $\boldsymbol{X}_{i}$, with inclusion of an error or disturbance term. The functional form of the binomial Logit model is as follows:

$$
\operatorname{Prob}\left[Y_{i}=1\right]=\varphi\left(\boldsymbol{\beta}, \boldsymbol{X}_{i}\right)=P_{i}+\varepsilon_{i}=\frac{e^{\boldsymbol{\beta} \boldsymbol{X}_{\boldsymbol{i}}}}{1+e^{\boldsymbol{\beta} \boldsymbol{X}_{\boldsymbol{i}}}}+\varepsilon_{i} \quad(i=1, \ldots, 86)
$$

where $\beta$ is a fixed but unknown parameter vector; $\mathrm{Xi}$ is a vector that integrates the explanatory variables or characteristics, which are assumed to be fixed in the sample; and $\varepsilon i$ is a random disturbance that is assumed to be normally distributed, with zero mean and unknown variance $\sigma 2$, where $\mathrm{Pi}$ is the probability of success and, therefore, 1-Pi is the probability of failure. The probability Pi of 'success' will simply be the mathematical expectation of the equation (1):

$$
P_{i}=E\left(Y=1 / X_{i}\right)=\frac{1}{1+e^{-z_{i}}}=\frac{e^{z_{i}}}{1+e^{z_{i}}}
$$

where $z_{i}=\boldsymbol{\beta} \boldsymbol{X}_{i}$, meaning that if $-\infty \leq z_{i} \leq \infty$ then $0 \leq P_{i} \leq 1$. Analogously, the probability of 'failure' is given by:

$$
1-P_{i}=E\left(Y=0 / X_{i}\right)=\frac{1}{1+e^{z_{i}}}
$$

with the quotient of the two probabilities $\Omega_{i}=e^{z_{i}}$ being the odds ratio, which will be a quantity defined in $[0, \infty)$. When comparing two individuals or options the odds ratio is often used, which is obtained from the quotient:

$$
\psi_{i j}=\frac{\Omega_{i}}{\Omega_{j}}=e^{z_{i}-z_{j}}
$$

Therefore, if $\psi_{\mathrm{ij}}>1$ this indicates a preference or advantage for the $\mathrm{i}$-th individual or option, while otherwise the advantage would be for the $\mathrm{j}$-th option. The neperian logarithm of the odds ratio, called the Logit, may simply be expressed as the difference between the estimated model evaluated at the $i$-th observation and the estimated model evaluated at the $j$ th observation.

\subsection{Results}

Different models were estimated based on maximum likelihood, estimating the variancecovariance matrix using the Huber-White procedure (Huber, 1981) to seek to explain the probability of obtaining a Senior University Lecturer post, in which variables different from 
those contained in the Annex have been incorporated. The models were selected on the basis of the usual comparisons, the criteria of the logarithmic likelihood function and the criteria of Akaike, Schwarz and Hannan-Quinn.

Table no. 2 - Results of the estimation and validity statistics

\begin{tabular}{|c|c|c|c|}
\hline Variable & Model 1 & Model 2 & Model 3 \\
\hline \multirow{2}{*}{ CONSTANT } & 61.6550 & $66.897^{* *}$ & 64.9182 \\
\hline & $(18.0323)$ & $(19.5731)$ & $(18.3279)$ \\
\hline \multirow{2}{*}{ NUMAYU1 } & 5.5262 & 3.8666 & 5.4817 \\
\hline & $(2.0322)$ & $(3.3062)$ & $(1.5675)$ \\
\hline \multirow{2}{*}{ ANOS_TESIS } & -1.0397 & -1.1247 & -1.0508 \\
\hline & $(0.3956)$ & $(0.2925)$ & $(0.3046)$ \\
\hline \multirow{2}{*}{ F_LIC-1966 } & -2.0963 & -2.2496 & -2.2126 \\
\hline & $(0.6551)$ & $(0.6994)$ & $(0.6551)$ \\
\hline \multirow{2}{*}{ SEXO*NUMAYU1 } & -2.9594 & $-1.7851^{* *}$ & -2.4849 \\
\hline & $(1.4118)$ & $(1.5055)$ & $(0.8967)$ \\
\hline \multirow{2}{*}{ SEXO } & & $-1.8575^{* *}$ & $-1.1122^{* * *}$ \\
\hline & & $(2.2282)$ & $(1,948)$ \\
\hline \multirow{2}{*}{ TITULO01 } & 18.7245 & 20.3439 & 20,123 \\
\hline & $(6.7824)$ & $(5.4759)$ & $(5.5589)$ \\
\hline \multirow{2}{*}{ CITASDOC } & -6.0703 & -6.8049 & -6.5951 \\
\hline & $(1.4656)$ & $(2.1712)$ & $(1.9912)$ \\
\hline \multirow{2}{*}{ DOC_S_M } & 6.0708 & $5.9934^{* *}$ & 6.6366 \\
\hline & $(2.1489)$ & $(3.1703)$ & $(2.1227)$ \\
\hline \multirow{2}{*}{ LIC_1PUBANU } & -1.4160 & -1.4363 & -1.4294 \\
\hline & -0.3980 & $(0.3638)$ & $(0.3537)$ \\
\hline \multirow{2}{*}{ ANTROPO } & & $1.5439^{* *}$ & $1.2847^{* * *}$ \\
\hline & & $(-1.9370)$ & $(1.6866)$ \\
\hline \multirow{2}{*}{ H_INDEX_S } & $1.9532^{* *}$ & 2.0788 & 1.7858 \\
\hline & $(1.0565)$ & $(0.8076)$ & $(0.6126)$ \\
\hline \multirow{2}{*}{ TESREL1 } & & $2.2772^{* *}$ & \\
\hline & & $(3.6881)$ & \\
\hline \multirow[t]{2}{*}{ PREDOC*NUMAYU1 } & & $1.1133^{* * *}$ & \\
\hline & & $(-1.4760)$ & \\
\hline McFadden R-squared & 0.894866 & 0.896736 & 0.896489 \\
\hline Akaike info criterion & 0.370007 & 0.460586 & 0.414398 \\
\hline Schwarz criterion & 0.655397 & 0.860131 & 0.756865 \\
\hline Hannan-Quinn criter. & 0.484863 & 0.621384 & 0.552225 \\
\hline Log likelihood & -5.910315 & -5.910315 & -5.819099 \\
\hline LR statistic & 100.6132 & 100.8235 & 100.7957 \\
\hline $\begin{array}{l}\text { Expectation/Prediction } \\
\text { Evaluation Test }(\%)\end{array}$ & $95.82 \%$ & $95.89 \%$ & $95.90 \%$ \\
\hline
\end{tabular}

The variables used in the models finally selected are shown in Table no. 2, as well as the estimate results. As can be seen in Table no. 2, the signs of the coefficients of the variables are theoretically consistent with what would be expected, verifying the positive influence of 
the number of grants received (NUMAYU) on the probability of obtaining an SUL position, with a greater effect in the case of male as opposed to female teaching staff; a negative effect on the dependent variable of the number of years the individual took to defend the doctoral thesis with respect to the graduation date (ANOS_TESIS); a negative influence on the 'graduation date' variable (F_LIC), which reflects an increase in difficulty obtaining a post both due to regulatory changes and the increased requirement for research merit. All the variables relating to scientific production have a positive effect, except for the average number of citations per document (CITAS DOC) in the DIALNET database, which must be related to a higher or lower number of scientific documents given that both variables have an inverse relationship. In fact, both the average annual number of articles (DOC_S_M) indexed in SCOPUS and the h-index extracted from SCOPUS (H_INDEX_S) for each researcher have a positive effect on the successful development of academic careers, as is to be expected. Likewise, the number of years elapsed from graduation until the first publication by the researcher (LIC_1PUBANU) has a negative influence, a result that is also expected and coincides with other studies.

The positive effect on probability of success of the prestige or quality of the university in which the individual provides their services is also relevant. For the universities that offer a Bachelor's Degree in Social or Cultural Anthropology (TITULACION), namely the universities of Seville and Granada as mentioned earlier, the probability is greater than in the other universities. This may also be due to the greater number of places and their greater consolidation. Because they are the universities with the highest number of lecturers, social aspects and the continuity of consolidated groups may also have an influence in this result. Inclusion as an explanatory variable of the dummy relating to the undergraduate qualification obtained - anthropology and another different one - is not significant. This is due, as has already been mentioned, to the recent introduction of these degrees in Spain. In some models, two variables were introduced relating to the influence the funding had on the development of the research career: the PREDOC variable, which reflects whether the individual had not yet obtained a doctorate at the time of receiving the first grant; and the TESREL variable, which reflects whether the subject of the doctoral thesis was related to the grant received or not. However, these variables are not significant at $95 \%$.

RESID

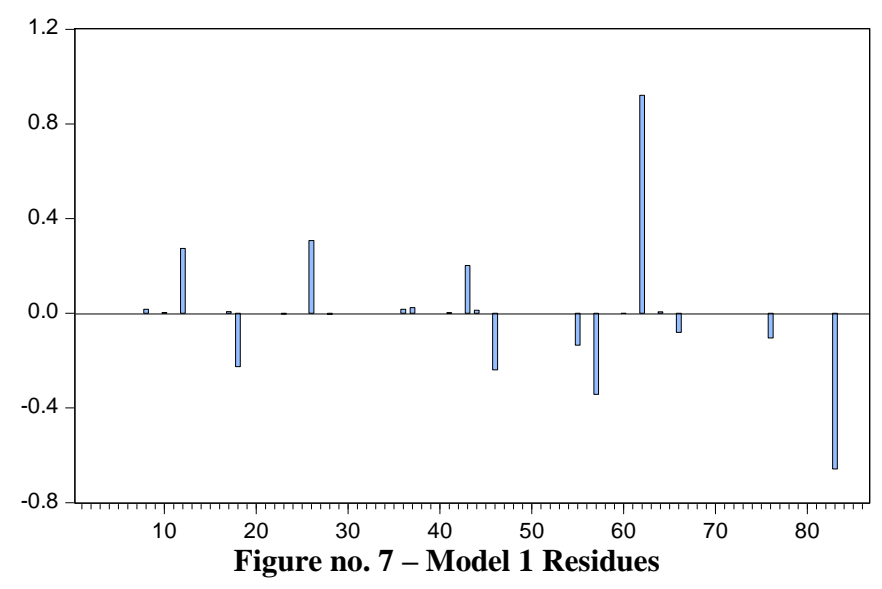


The estimators of the parameters contained in the vector $\boldsymbol{\beta}$ of the three models are globally significant with significance levels close to zero based on the likelihood ratio (LR) test, which is distributed as an $\chi^{2}$ with $\mathrm{k}$ degrees of freedom. However, as we have commented and as indicated in the Table, some coefficients contained in the models are not significant at $95 \%$. Of the three models shown, we will comment on the results of Model 1 , since it is preferable to the others according to the usual criteria. Moreover, there is only one variable that is not significant at $95 \%$ - the variable H_Index_S - although it is significant at $90 \%$. The predictive evaluation of the models - with probabilities approximated to $0.5 \%$ - is very similar, given that all three correctly predict the situation of the individuals in proportions above $95 \%$. In fact, there is only one person who was a senior university lecturer and should not have been one according to the model, and another person who, with the variables considered, should have already obtained a post as a senior university lecturer but has not yet done so, and in that case it is mainly due to having spent many years in Latin American universities before returning to Spain, despite having been trained in Andalusia.

\subsection{Discussion}

We will now turn to the main focus of our analysis: to analyse the effect of the ethnological research grants offered by the Ministry of Culture of the Andalusian Autonomous Government on the success of academic careers. This required us to obtain the marginal effect of the variable NUMAYU, which measures the number of grants received by each lecturer. To obtain this marginal effect, the interpretation of which is not as obvious as in linear models, we derive the function $\varphi(\boldsymbol{X i}, \boldsymbol{\beta})$ of (1) with respect to the explanatory variable for which the marginal effect is to be obtained, so that where this variable is $X_{j}$ we would obtain:

$$
\frac{\partial \varphi\left(\boldsymbol{\beta}_{\boldsymbol{i}}\right)}{\partial X_{j}}=P_{i}\left(1-P_{i}\right) \beta_{j}
$$

where $\beta \mathrm{j}$ is the coefficient of the variable $\mathrm{Xj}$ in (1), and where Pi would be substituted with its estimation evaluated as the mean value of the sample items. In our case the relevant variable, NUMAYU, appears in two terms, in one on its own and in the other as an interaction term for gender, so that we would have:

$$
\begin{gathered}
\frac{\partial \varphi\left(\boldsymbol{\beta}_{\boldsymbol{i}}\right)}{\partial N U M A Y U}=P_{i}\left(1-P_{i}\right) 5.53 \text { for men } \\
\frac{\partial \varphi\left(\boldsymbol{\beta}_{\boldsymbol{i}}\right)}{\partial N U M A Y U}=P_{i}\left(1-P_{i}\right) 5.53-2.964 \text { for women }
\end{gathered}
$$

It can clearly be seen that for the same values of the $\mathrm{Xi}$ in the function $\varphi(\mathrm{Xi}, \boldsymbol{\beta})$, the marginal effect of the Ethnological Campaign grants on the academic careers of teaching staff is very different according to gender. The marginal effect - the increase in the probability of a unit change in the explanatory variable - is much greater for men than for women. Obviously, the marginal effect depends on the value of the probability of success Pi for each individual, i.e. it depends on the value of the explanatory variables. Evaluating the explanatory variables at their mean value, the marginal effect for men in the case of small universities 
increases the probability of obtaining an SUL post by $56.3 \%$, while for women in the same situation it only increases by $14.2 \%$.

In order to better show the effect of the grants received under the Ethnological Campaigns on the academic careers of teaching staff in the area of knowledge of Social Anthropology in Andalusia, different categories of teaching staff have been established according to their gender, whether or not the university offers bachelor's degrees in social and cultural anthropology (an indicator of the size of the university) and applying three different levels of scientific production, namely the global average (Medium), 1/2 of the global average (Low) and 3/2 of the global average (High). The results are shown in Table no. 3, clearly confirming that with high production in all the segments considered the probability of achieving a post is practically $100 \%$, regardless of the aid received.

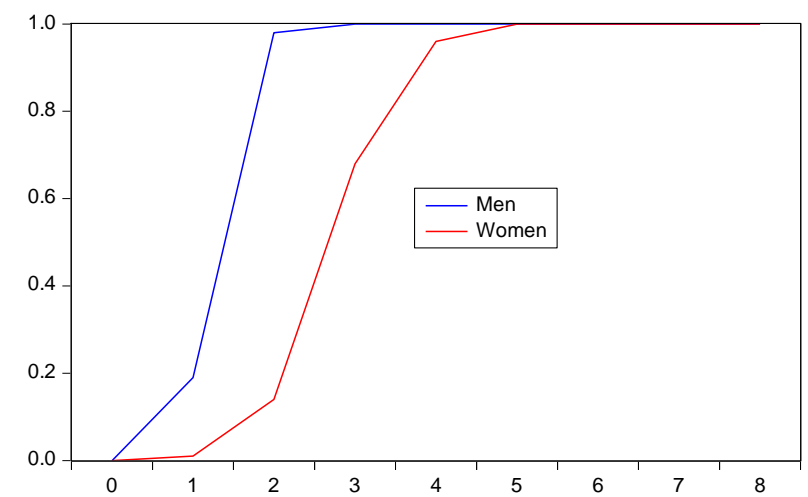

Figure no. 8 - Probability of obtaining a post with medium scientific productivity

When the production is medium and the university is large (it offers the degree course), the probability of success is also $100 \%$. However, if the university is small then differences begin to emerge: only men receiving more than one grant would achieve a post while women with equivalent scientific production and other characteristics (time taken to read the thesis and years elapsed until the first publication) would have to receive more than 2 or 3 grants to have a $100 \%$ probability of obtaining a post (Figure no. 8 ).

Table no. 3 - Changes in the probability of 'success' as a function of the number of grants received and social-professional characteristics of teaching staff

\begin{tabular}{|c|c|c|c|c|c|c|c|c|c|c|c|c|}
\hline \multirow{3}{*}{$\begin{array}{c}\text { NO. } \\
\text { GRANTS }\end{array}$} & \multicolumn{4}{|c|}{ MEDIUM PRODUCTION } & \multicolumn{4}{|c|}{ LOW PRODUCTION } & \multicolumn{4}{|c|}{ HIGH PRODUCTION } \\
\hline & \multicolumn{2}{|c|}{ Small Univ. } & \multicolumn{2}{|c|}{ Large Univ. } & \multicolumn{2}{|c|}{ Small Univ. } & \multicolumn{2}{|c|}{ Large Univ. } & \multicolumn{2}{|c|}{ Small Univ. } & \multicolumn{2}{|c|}{ Large Univ. } \\
\hline & $\mathbf{M}$ & $\mathbf{F}$ & $\mathbf{M}$ & $\mathbf{F}$ & $\mathbf{M}$ & $\mathbf{F}$ & M & $\mathbf{F}$ & $\mathbf{M}$ & $\mathbf{F}$ & $\mathbf{M}$ & $\mathbf{F}$ \\
\hline 0 & 0.00 & 0.00 & 1.00 & 1.00 & 0.00 & 0.00 & 0.00 & 0.00 & 1.00 & 1.00 & 1.00 & 1.00 \\
\hline 1 & 0.19 & 0.01 & 1.00 & 1.00 & 0.00 & 0.00 & 0.00 & 0.00 & 1.00 & 1.00 & 1.00 & 1.00 \\
\hline 2 & 0.98 & 0.14 & 1.00 & 1.00 & 0.00 & 0.00 & 0.00 & 0.00 & 1.00 & 1.00 & & 1.00 \\
\hline 3 & 1.00 & 0.68 & 1.00 & 1.00 & 0.00 & 0.00 & 0.00 & 0.00 & 1.00 & 1.00 & 1.00 & 1.00 \\
\hline 4 & 1.00 & 0.96 & 1.00 & 1.00 & 0.00 & 0.00 & 0.31 & 0.00 & 1.00 & 1.00 & 1.00 & 1.00 \\
\hline 5 & 1.00 & 1.00 & 1.00 & 1.00 & 0.00 & 0.00 & 0.99 & 0.00 & 1.00 & 1.00 & 1.00 & 1.00 \\
\hline 6 & 1.00 & 1.00 & 1.00 & 1.00 & 0.00 & 0.00 & 1.00 & 0.00 & 1.00 & 1.00 & 1.00 & 1.00 \\
\hline 7 & 1.00 & 1.00 & 1.00 & 1.00 & 0.05 & 0.00 & 1.00 & 0.01 & 1.00 & 1.00 & 1.00 & 1.00 \\
\hline 8 & 1.00 & 1.00 & 1.00 & 1.00 & 0.93 & 0.00 & 1.00 & 0.09 & 1.00 & 1.00 & 1.00 & 1.00 \\
\hline
\end{tabular}


Finally, when the scientific production is low and the university is small, the chances of obtaining a post are significantly reduced, so that only men with 8 grants - the maximum observed - would be assured a post, while women would not be assured a post at all. On the contrary, in large universities men with more than four grants would be assured a post with this level of production while women, despite having received grants and regardless of their number, would have zero probability.

\section{CONCLUSIONS}

The Ethnological Campaign programme was among the first activities proposed by the Ministry of Culture of the Andalusian Autonomous Government after it took over responsibility for this area in 1984. However, for various reasons, its implementation did not commence until 1988, when the first 21 grants were awarded. Its objectives were to foster training of Andalusian anthropologists through applied research that would enable the documentation, dissemination and recuperation of Andalusia's ethnological heritage. Altogether, a total of 274 different grants were awarded between 1988 and 2009 to 151 researchers who, to a large extent, were thereby able to complete their doctoral theses and also to integrate themselves and consolidate their position on the staff of the different Andalusian universities and, to a lesser extent, other universities in the surrounding area (University of Extremadura, Miguel Hernández University of Elche, University of Murcia). Of the 274 grants awarded, 84 were used to complete the recipients' doctoral theses, while others were used to consolidate their research careers after they had obtained their $\mathrm{PhD}$. Of the 151 grant recipients, almost $38 \%$ were researchers who later joined the university departments, where they still make up the vast majority of the permanent teaching staff. Gradually, the funds allocated to this programme were reduced until they disappeared in 2010 as a consequence of the economic crisis and also as a result of the progressive loss of importance of cultural activities in the budgets of the Autonomous Community.

As we have seen, these grants had a decisive influence on the academic careers of lecturers in the emerging area of knowledge of Social Anthropology in Andalusia. Of the 86 full-time lecturers in Andalusian universities, 56\% received support from the administration, whether in the form of grants, scholarships or even publications. These were specific programmes for this group of beneficiaries, whose only parallel, if any, can be found in the area of archaeology, constituting a positive marginalisation that other areas of knowledge did not benefit from. However, as has been shown, the effects of these policies on the academic careers of the teaching staff were not uniform. Despite having identical scientific output, the marginal effect of the grants was much greater for men than for women. Moreover, they benefited large universities to a greater extent than small ones. The control of the Ethnology Committee by professors from these universities and the very structure of the research groups, departments and promotion policies of the universities largely explains these results.

\section{ORCID}

Celeste Jiménez de Madariaga (iD https://orcid.org/0000-0001-8389-0464

Juan José García del Hoyo (iD https://orcid.org/0000-0002-6132-8566 


\section{References}

Agudo Torrico, J. (1997). Patrimonio Etnologico. Problematica en torno a su Definicion y Objetivos. PH. Boletín del Instituto Andaluz de Patrimonio Histórico, 18, 97-108.

Aguilar Criado, E. (1992). Treinta anos de antropologia andaluza (1960-1990). Anales de la Fundación Joaquín Costa, 9, 83-100.

Allison, P. D., \& Stewart, J. A. (1974). Productivity Differences Among Scientists: Evidence for Accumulative Advantage. American Sociological Review, 39(4), 596-606. http://dx.doi.org/10.2307/2094424

Aran, L., \& Ben-David, J. (1968). Socialization and career patterns as determinants of productivity of medical researchers. Journal of Health and Social Behavior, 9(1), 3-15. http://dx.doi.org/10.2307/2948313

Baird, L. L. (1991). Publication Productivity in Doctoral Research Departments: Interdisciplinary and Intradisciplinary Factors. Research in Higher Education, 32(3), 303-318. http://dx.doi.org/10.1007/BF00992894

Becerra Garcia, J. M. (1999). La legislacion espanola sobre patrimonio historico, origen y antecedentes. La ley del patrimonio historico andaluz V Jornadas sobre la Historia de Marchena. El patrimonio y su conservacion (pp. 9-30): Marchena.

Bozeman, B., Dietz, J. S., \& Gaughan, M. (2001). Scientific and technical human capital: An alternative model for research evaluation. International Journal of Technology Management, 22(7/8), 716740. http://dx.doi.org/10.1504/IJTM.2001.002988

Dietz, J. S., \& Bozeman, B. (2005). Academic careers, patents, and productivity: Industry experience as scientific and technical human capital. Research Policy, 34(3), 349-367. http://dx.doi.org/10.1016/j.respol.2005.01.008

Huber, P. J. (1981). Robust Statistics: John Wiley \& Sons. http://dx.doi.org/10.1002/0471725250

Jiménez De Madariaga, C., \& Checa Olmos, F. (2012). Treinta años de Antropología en España: Memoria desde La Gazeta. Gazeta de Antropología, 1-11.

Jimenez Nunez, A. (2008). La Antropologia en Andalucia (1960-1985). Breve memoria para jovenes y desmemoriados Aportaciones de la Antropologia Social y Cultural al conocimiento de Andalucia (pp. 8-16): Centro de Estudios Andaluces.

Jonkers, K. (2011). Mobility, productivity, gender and career development of Argentinean life scientists. Research Evaluation, 20(5), 411-421. http://dx.doi.org/10.3152/095820211X13176484436177

Junta de Andalucía. (1987). Programas de Cultura Programa Andaluz de Desarrollo Economico 19871990 (pp. 218-221). Sevilla: Consejeria de Economia y Hacienda.

Junta de Andalucía. (1991). Anuario Etnologico de Andalucia 1988/90. Sevilla: Consejeria de Cultura y Medioambiente. Direccion General de Bienes Culturales.

Junta de Andalucía. (1992). Anuario Etnologico de Andalucia 1991. Sevilla: Consejeria de Cultura y Medioambiente. Direccion General de Bienes Culturales.

Junta de Andalucía. (1994). Anuario Etnologico de Andalucia 1992/93. Sevilla: Consejeria de Cultura. Direccion General de Bienes Culturales.

Junta de Andalucía. (1996). Anuario Etnologico de Andalucia 1994. Sevilla: Consejeria de Cultura. Direccion General de Bienes Culturales.

Junta de Andalucía. (1999). Anuario Etnologico de Andalucia 1995-1997. Sevilla: Consejeria de Cultura. Direccion General de Bienes Culturales.

Junta de Andalucía. (2000). Anuario Etnologico de Andalucia 1998-1999. Sevilla: Consejeria de Cultura. Direccion General de Bienes Culturales.

Junta de Andalucía. (2002). Anuario Etnologico de Andalucia 2000-2001. Sevilla: Consejeria de Cultura. Direccion General de Bienes Culturales.

Junta de Andalucía. (2006). Anuario Etnologico de Andalucia 2002-2003. Sevilla: Consejeria de Cultura. Direccion General de Bienes Culturales.

Kramer, J. S. (1991). The LOGIT model for economists: Edward Arnold Publishers. 
Lizarazu de Mesa, M. A. (1996). Culturas e identidades: Politicas actuales sobre el patrimonio etnografico en Espana. Complutum, 6(2), 337-346.

Long, J. S., \& Fox, M. F. (1995). Scientific Careers: Universalism and Particularism. Annual Review of Sociology, 21(1), 45-71. http://dx.doi.org/10.1146/annurev.so.21.080195.000401

Maddala, G. S. (1983). Limited Dependent and Qualitative Variables in Econometrics: Cambridge University Press. http://dx.doi.org/10.1017/CBO9780511810176

Melin, G. (2005). The dark side of mobility: Negative experiences of doing a postdoc period abroad. Research Evaluation, 14(3), 229-237. http://dx.doi.org/10.3152/147154405781776102

Moreno Navarro, I. (1973). La investigación antropológica en España. In A. Jiménez Núñez (Ed.), Reunión de Antropólogos Españoles (pp. 325-338). Sevilla: Universidad de Sevilla.

Moreno Navarro, I. (1991). Patrimonio etnografico, estudios etnologicos y Antropologia en Andalucia: Estudios y Perspectivas. In A. Valdes (Ed.), Anuario Etnologico de Andalucia 1988-1990 (pp. 915): Consejeria de Cultura y Medio Ambiente, Junta de Andalucia.

Morrison, E., Rudd, E., \& Nerad, M. (2011). Onto, Up, Off the Academic Faculty Ladder: The Gendered Effects of Family on Career Transitions for a Cohort of Social Science Ph.D.s. Review of Higher Education, 34(4), 525-553. http://dx.doi.org/10.1353/rhe.2011.0017

Nakhaie, M. R. (2007). Universalism, Ascription and Academic Rank: Canadian Professors, 19872000*. Canadian Review of Sociology/Revue canadienne de sociologie, 44(3), 361-386. http://dx.doi.org/10.1111/j.1755-618X.2007.tb01190.x

Neumann, A., \& Terosky, A. L. (2007). To Give and to Receive: Recently Tenured Professors' Experiences of Service in Major Research Universities. Journal of Higher Education, 78(3), 282310. http://dx.doi.org/10.1080/00221546.2007.11772317

Pérez Yruela, M., \& Vives, P. A. (2012). La política cultural en Andalucía. RIPS: Revista De Investigaciones Políticas Y Sociológicas, 11(3).

Ruiz Robledo, A. (1999). La Constitucion cultural espanola. La Ley, Revista Jurídica Española de Doctrina. Jurisprudencia y Bibliografía, 2, 1691-1702.

Sabatier, M. (2010). Do female researchers face a glass ceiling in France? A hazard model of promotions. Applied $\quad$ Economics, 2053-2062. http://dx.doi.org/10.1080/00036840701765338

Sanz-Menéndez, L., Cruz-Castro, L., \& Alva, K. (2013). Time to Tenure in Spanish Universities: An $\begin{array}{lllll}\text { Event History Analysis. PLOS ONE, } & \text { 8(10), } 77028 .\end{array}$ http://dx.doi.org/10.1371/journal.pone.0077028

Tien, F. F. (2007). To what degree does thepromotion system reward faculty research productivity? British Journal of Sociology of Education, 28(1), 105-123. http://dx.doi.org/10.1080/01425690600996741

Wolfinger, N. H., Mason, M. A., \& Goulden, M. (2008). Problems in the Pipeline: Gender, Marriage, and Fertility in the Ivory Tower. The Journal of Higher Education, 79(4), 388-405. http://dx.doi.org/10.1080/00221546.2008.11772108

Xie, Y., \& Shauman, K. A. (2003). Women in science: career processes and outcomes: Harvard University Press. 
ANNEX

List of the variables used and their sources

\begin{tabular}{|c|c|c|c|}
\hline VARIABLE & TYPES & DESCRIPTION & SOURCES \\
\hline F_LIC & Numeric & Year of obtaining the Bachelor's Degree & $\begin{array}{l}\text { Public CVs \& University web } \\
\text { pages }\end{array}$ \\
\hline$\overline{\text { UNIV_LIC }}$ & Text & University of obtaining the Bachelor's Degree & $\begin{array}{l}\text { Public CVs \& University web } \\
\text { pages }\end{array}$ \\
\hline TIT_LIC & Text & Denomination of the Degree & $\begin{array}{l}\text { Public CVs \& University web } \\
\text { pages }\end{array}$ \\
\hline ANTROPO & Dummy & Anthropology degree $=1 ;$ Other degrees $=0$ & $\begin{array}{l}\text { Public CVs \& University web } \\
\text { pages }\end{array}$ \\
\hline$\overline{\text { LIC_EXT }}$ & Dummy & Foreign University Bachelor $=1$; Other $=0$ & $\begin{array}{l}\text { Public CVs \& University web } \\
\text { pages }\end{array}$ \\
\hline$\overline{\text { LIC_NOAND }}$ & Dummy & Bachelor of Andalusian University $=1 ;$ Other $=0$ & $\begin{array}{l}\text { Public CVs \& University web } \\
\text { pages }\end{array}$ \\
\hline F_TESIS & Numeric & Date of the Ph.D. degree & $\begin{array}{l}\text { Public CVs \& University web } \\
\text { pages }\end{array}$ \\
\hline UNIV_TES & Text & University in which he obtained the title of Doctor & $\begin{array}{l}\text { Public CVs \& University web } \\
\text { pages }\end{array}$ \\
\hline TITULO & Text & Name of the title of Doctor & $\begin{array}{l}\text { Public CVs \& University web } \\
\text { pages }\end{array}$ \\
\hline TES_EXT & Dummy & Thesis defended at a foreign University $=1 ;$ Other $=0$ & $\begin{array}{l}\text { Public CVs \& University web } \\
\text { pages }\end{array}$ \\
\hline TES_NOAND & Dummy & $\begin{array}{l}\text { Thesis defended at an Andalusian University }=1 \text {; } \\
\text { Other }=0\end{array}$ & $\begin{array}{l}\text { Public CVs \& University web } \\
\text { pages }\end{array}$ \\
\hline ENDOTES & Dummy & $\begin{array}{l}\text { Thesis defended at the same university where he obtained } \\
\text { his degree }=1 \text {; Other }=0\end{array}$ & $\begin{array}{l}\text { Public CVs \& University web } \\
\text { pages }\end{array}$ \\
\hline ANOS_TESIS & Numeric & $\begin{array}{l}\text { Number of years between the Doctoral Thesis and the } \\
\text { Bachelor's Degree }\end{array}$ & $\begin{array}{l}\text { Public CVs \& University web } \\
\text { pages }\end{array}$ \\
\hline F_PTU & Numeric & Year of obtaining a university professor position & $\begin{array}{l}\text { Public CVs \& University web } \\
\text { pages }\end{array}$ \\
\hline ENDO_PTU & Dummy & $\begin{array}{l}\text { Senior Lecturer position at the same university where the } \\
\text { doctoral thesis was defended }=1 ; \text { Other }=0\end{array}$ & $\begin{array}{l}\text { Public CVs \& University web } \\
\text { pages }\end{array}$ \\
\hline DEPEN_PTU & Dummy & $\begin{array}{l}\text { Professor previously hired at the same university where he } \\
\text { obtained a Senior Lecturer }=1 \text {; Other }=0\end{array}$ & $\begin{array}{l}\text { Public CVs \& University web } \\
\text { pages }\end{array}$ \\
\hline$\overline{\text { F_CU }}$ & Numeric & Year of obtaining the position of Full Professor & $\begin{array}{l}\text { Public CVs \& University web } \\
\text { pages }\end{array}$ \\
\hline DEPEN_CU & Dummy & $\begin{array}{l}\text { Previously Senior Lecturer at the same university }=1 \text {; } \\
\text { Other }=0\end{array}$ & $\begin{array}{l}\text { Public CVs \& University web } \\
\text { pages }\end{array}$ \\
\hline ANOS_PTU & Numeric & $\begin{array}{l}\text { Number of years between obtaining the position of senior } \\
\text { lecturer and that of Full Professor }\end{array}$ & $\begin{array}{l}\text { Public CVs \& University web } \\
\text { pages }\end{array}$ \\
\hline NUMAY & Numeric & No. of grants received Ethnological Research Programs & $\begin{array}{l}\text { Official Gazette of the Junta de } \\
\text { Andalucía (BOJA) }\end{array}$ \\
\hline Q_AYUD & Numeric & Monetary amount received for aid (in $€ 2016$ ) & $\begin{array}{l}\text { Official Gazette of the Junta de } \\
\text { Andalucía (BOJA) }\end{array}$ \\
\hline Q_BECA & Numeric & Amount received for scholarships (in $€ 2016$ ) & $\begin{array}{l}\text { Official Gazette of the Junta de } \\
\text { Andalucía (BOJA) }\end{array}$ \\
\hline Q_TOT & Numeric & Total amount received (in $€ 2016$ ) & $\begin{array}{l}\text { Official Gazette of the Junta de } \\
\text { Andalucía (BOJA) }\end{array}$ \\
\hline TESREL1 & Dummy & $\begin{array}{l}\text { Thesis related to the subject of all the grants received from } \\
\text { the Program }=1 ; \text { Others }=0\end{array}$ & $\begin{array}{l}\text { Official Gazette of the Junta de } \\
\text { Andalucía (BOJA) }\end{array}$ \\
\hline TESREL2 & Dummy & $\begin{array}{l}\text { Thesis related to the subject of grants only Ethnological } \\
\text { Research }=1 ; \text { Others }=0\end{array}$ & $\begin{array}{l}\text { Official Gazette of the Junta de } \\
\text { Andalucía (BOJA) }\end{array}$ \\
\hline T_FBI & Dummy & $\begin{array}{l}\text { Blas Infantes Foundation Thesis Publication }=1 ; \text { Other }= \\
0\end{array}$ & $\begin{array}{l}\text { Blas Infantes Foundation web } \\
\text { page }\end{array}$ \\
\hline
\end{tabular}




\begin{tabular}{|c|c|c|c|}
\hline VARIABLE & TYPES & DESCRIPTION & SOURCES \\
\hline Mono_et & Dummy & $\begin{array}{l}\text { Publication of the thesis in the Ethnology monograph } \\
\text { collection of the Junta de Andalucía }=1 ; \text { Other }=0\end{array}$ & $\begin{array}{l}\text { Official Gazette of the Junta de } \\
\text { Andalucía (BOJA) }\end{array}$ \\
\hline NUMAYU1 & Numeric & Total number of grants received & Own elaboration \\
\hline PREDOC & Dummy & $\begin{array}{l}\text { Ethnology grants obtained before defense of thesis } \\
\text { doctoral = 1; Other }=0\end{array}$ & Own elaboration \\
\hline 1a_dialnet & Numeric & Year of first publication registered & DIALNET database \\
\hline Lic_1pub & Numeric & $\begin{array}{l}\text { Number of years between obtaining a degree and the first } \\
\text { registered publication }\end{array}$ & $\begin{array}{l}\text { DIALNET database \& Public } \\
\text { CVs }\end{array}$ \\
\hline$\overline{\text { ANU_TOT }}$ & Numeric & Number of publications in the Ethnology Yearbooks & $\begin{array}{l}\text { Own elaboration from } \\
\text { ethnology yearbooks }\end{array}$ \\
\hline$\overline{\text { ANU_1PUB }}$ & Numeric & Year of first publication in the Ethnology Yearbook & $\begin{array}{l}\text { Own elaboration from } \\
\text { ethnology yearbooks }\end{array}$ \\
\hline ANU_DUM & Dummy & $\begin{array}{l}\text { Ethnology Yearbook publication is first registered } \\
\text { publication = } 1 ; \text { Other }=0\end{array}$ & $\begin{array}{l}\text { DIALNET database, Public } \\
\text { CVs \& Own elaboration }\end{array}$ \\
\hline $\begin{array}{l}\text { PUBTOT_AN } \\
\text { U }\end{array}$ & $\mathrm{Nu}$ & $\begin{array}{l}\text { Total number of publications in DIALNET + Ethnology } \\
\text { Yearbooks }\end{array}$ & $\begin{array}{l}\text { DIALNET database, Public } \\
\text { CVs \& Own elaboration }\end{array}$ \\
\hline ANO_1PUB1 & Numeric & $\begin{array}{l}\text { Year of the first publication in the Ethnology Yearbook } \\
\text { and DIALNET }\end{array}$ & $\begin{array}{l}\text { DIALNET database, Public } \\
\text { CVs \& Own elaboration }\end{array}$ \\
\hline $\begin{array}{l}\text { LIC_1PUBA } \\
\mathrm{U}\end{array}$ & & $\begin{array}{l}\text { Number of years since the degree and the 1st publication } \\
\text { (Yearbooks of ethnology + DIALNET) }\end{array}$ & DIALNET database \\
\hline$\overline{\text { ARTI }}$ & Numeric & Number of articles registered in DIALNET & DIALNET database \\
\hline$\overline{\mathrm{CLIB}}$ & Numeric & No. of Book Chapters registered in DIALNET & DIALNET database \\
\hline$\overline{\mathrm{LIB}}$ & Numeric & No. of books registered in DIALNET & DIALNET database \\
\hline TESIS & Numeric & Number of supervised doctoral theses reg & DIALNET database \\
\hline CITAS & Numeric & Number of citations received registered in DIALNET & DIALNET database \\
\hline PUBTOT & Numeric & Number of total publications registered in DIALNET & DIALNET database \\
\hline$\overline{\text { CITASDOC }}$ & Numeric & $\begin{array}{l}\text { Average number of citations received per document } \\
\text { registered in DIALNET }\end{array}$ & $\begin{array}{l}\text { DIALNET database \& Public } \\
\text { CVs }\end{array}$ \\
\hline$\overline{\text { ARTIM }}$ & Numeric & $\begin{array}{l}\text { Number of articles registered in DIALNET / years since } \\
\text { thesis }\end{array}$ & $\begin{array}{l}\text { DIALNET database \& Public } \\
\text { CVs }\end{array}$ \\
\hline$\overline{\text { CLIBM }}$ & Numeric & No. of Book Chapters registered in DIALNET & $\begin{array}{l}\text { DIALNET database \& Public } \\
\text { CVs }\end{array}$ \\
\hline$\overline{\mathrm{LIBM}}$ & Numeric & No. of books registered in DIALNET / years since thesis & $\begin{array}{l}\text { DIALNET database \& Public } \\
\text { CVs }\end{array}$ \\
\hline TESISM & Numeric & $\begin{array}{l}\text { No. of supervised doctoral theses registered in DIALNET } \\
\text { / years since thesis }\end{array}$ & $\begin{array}{l}\text { DIALNET database \& Public } \\
\text { CVs }\end{array}$ \\
\hline$\overline{\text { CITASm }}$ & Numeric & $\begin{array}{l}\text { Average number of citations received per document } \\
\text { registered in DIALNET / years since thesis }\end{array}$ & $\begin{array}{l}\text { DIALNET database \& Public } \\
\text { CVs }\end{array}$ \\
\hline PUBTOTM & Numeric & $\begin{array}{l}\text { No. of total publications registered in DIALNET / by } \\
\text { years since thesis }\end{array}$ & $\begin{array}{l}\text { DIALNET database \& Public } \\
\text { CVs }\end{array}$ \\
\hline Doc_s & Numeric & Number of publications registered in SCOPUS & SCOPUS database \\
\hline Citas_S & Numeric & $\begin{array}{l}\text { Appointments_S Number of citations received registered } \\
\text { in SCOPUS }\end{array}$ & SCOPUS database \\
\hline h_index_S & Numeric & H Index extracted from SCOPUS & SCOPUS database \\
\hline Doc_S_M & Numeric & number of articles from $y$ & SCOPUS database \& Public CVs \\
\hline Citas_s_m & Numeric & $\begin{array}{l}\text { Average number of citations received registered in } \\
\text { SCOPUS from year of thesis }\end{array}$ & SCOPUS database \& Public CVs \\
\hline index_sm & Numeric & Average H Index in SCOPUS from tear of thesis & SCOPUS database \& Public C \\
\hline amauni & Numer & Total number of anthropolog & eb pages \\
\hline titulo & Dummy & $\begin{array}{l}\text { Universities that offer a Bachelor's Degree in Social or } \\
\text { Cultural Anthropology }=1 ; \text { Other }=0\end{array}$ & Universities web pages \\
\hline Año_antro & Numeric & $\begin{array}{l}\text { Number of years from the firts course of anthropology in } \\
\text { the university }\end{array}$ & ties web pages \\
\hline ienero & Dummy & Female $=1 ;$ Male $=0$ & Public Cvs \\
\hline Edad & Numeric & Age as of PTU date & Public Cvs \\
\hline
\end{tabular}




\section{Notes}

1 Its functions included the "management, protection, inventory, restoration, enhancement and dissemination of historical, artistic, archaeological, palaeontological and ethnological heritage."

${ }^{2}$ In the opinion of Ruiz Robledo (1999), the 1978 Constitution provides the fundamental legal framework for the structure and functioning of Spanish cultural life, understood as including both the production and enjoyment of artistic, literary and scientific works and the various ways of life, customs and traditions that have developed throughout Spain (common cultural heritage), and also at regional and even local levels.

${ }^{3}$ Preliminary Title, Article 3(3): "The wealth of the different language modalities of Spain is a cultural heritage which shall be the object of special respect and protection."

4 "The public authorities shall guarantee the preservation and promote the enrichment of the historic, cultural and artistic heritage of the peoples of Spain and of the property of which it consists, regardless of its legal status and its ownership. Offences committed against this heritage shall be punished under criminal law." (Article 46).

${ }^{5}$ The reference to cultural heritage, together with Spanish artistic and monumental heritage, is repeated in Article 149(1) (28), in this case in the context of the exclusive competence of the State over the "protection of Spain's cultural and artistic heritage and national monuments against exportation and despoliation", but without prejudice to their management by the Autonomous Communities.

${ }^{6}$ Established by Decree 1398/1961 of 22 September creating the National Artistic, Archaeological and Ethnological Information Service, and structured pursuant to Decree 3963/1964 of 3 December into a central service, regional services and provincial services, without establishing any organisational rank.

${ }^{7}$ According to the terms of Royal Decree $1558 / 1977$ of 4 July restructuring certain bodies of the Central State Administration.

${ }^{8}$ Order of 5 June 1979 establishing the organisational rank of the Head Office of the National Centre for Artistic, Archaeological and Ethnological Information.

${ }^{9}$ Royal Decree 442/1981 of 6 March.

${ }^{10}$ More specifically, these functions consisted of: a) issuing of reports, when requested by the DirectorGeneral of Fine Arts, Archives and Libraries, on any provisions to be enacted for the protection, defence and research of historical and artistic heritage of an ethnological nature.

${ }^{11}$ Section 2 provides that the Directorate-General for Cultural Heritage has the following functions: "1) To direct and manage the services and resolve the affairs of the Ministry that fall within its competence, overseeing and supervising the departments under its responsibility and establishing their internal regulations. 2) To propose to the Regional Minister of Culture the Resolutions it deems appropriate in matters within its competence the processing of which corresponds to the Directorate-General. 3) The functions specifically delegated by the Regional Minister or Deputy Regional Minister and those attributed by the laws in force."

${ }^{12}$ However, in the Order of 25 May 1983 developing this structure, the names of the departments and divisions of the Service barely contemplate specific responsibilities in the field of ethnological heritage. ${ }^{13}$ We will come back to this budget later, as it was the first time that specific budget allocations had been included for ethnological research linked with archaeological research.

${ }^{14}$ See Law 10/1984 of 30 July on the Budget for the Autonomous Community of Andalusia for 1984 (BOJA No. 73 of 3 August 1984). At the time, 1 European Currency Unit $=127.58$ pesetas

${ }^{15}$ See Decree 12/1985 of 22 January establishing the organisational structure of the Regional Ministry of Culture (BOJA No. 14 of 14/02/1985).

${ }^{16}$ See Decree 210/1986 of 5 August modifying the organisational structure of the Regional Ministry of Culture (BOJA No. 78 of 9 August 1986).

${ }^{17}$ See Decree 259/1994 of 13 September on the Basic Organisational Structure of the Regional Ministry of Culture (BOJA No. 146 of 17 September 1994).

18 See Decree 333/1996 of 9 July, amending Decree 259/1994 of 13 September on the basic organisational structure of the Regional Ministry of Culture (BOJA No. 80 of 13/07/1996). 
${ }^{19}$ See Royal Decree 442/1981 of 6 March on the organisational structure of the Ministry of Culture (BOE No. 64 of 16 March 1981).

${ }^{20}$ See the Ministerial Order of 11 September 1981 (BOE No. 231 of 26 September 1981).

${ }^{21}$ Andalusian Autonomous Government (1984), Economic Plan for Andalusia 1984-1986, Seville: Regional Ministry of Economy and Finance, pp. 173-174.

22 Andalusian Regional Government, (1984), idem, pp. 88-92.

${ }^{23}$ Andalusian Regional Government, (1984), idem, pp. 174-177.

${ }^{24}$ Question Nos. 603/84 and 604/84 (Official Gazette of the Andalusian Parliament (BOPA) No. 176, 15 December 1984, pp. 3248 and 3249).

${ }_{25}$ Answer by the Government Council to Question Nos. 603/1984 and 604/1984 (BOPA No. 216, 12 April 1985, p.p. 4148-4150).

${ }^{26}$ It is likely that there was a specific call for proposals but that it was not published in the BOJA. The fact is that in subsequent years when referring to the start of the ethnological research grant programme, reference is made to the orders published from 1989 onwards, without any reference to the grants awarded in 1988.

27 As ethnographic heritage is defined in Law 16/1985 of 25 June 1985 on Spanish Historical Heritage (Ley 16/1985, de 25 de junio, del Patrimonio Histórico Español).

${ }^{28}$ Order of 22 May 1989 regulating the award of grants for ethnographic activities (BOJA No. 43 of 2 June 1989).

${ }^{29}$ Order of 25 November 1987 appointing the members and chairperson of the Andalusian Ethnology Committee (BOJA No. 7 of 19 January 1988).

${ }^{30}$ Section 13 of the Order of 22 May 1989 regulating the award of grants for ethnographic activities (BOJA No. 43 of 2 June 1989).

${ }^{31}$ Resolution of 29 July 1975 of the Directorate-General for Universities and Research, determining the inclusion in the third year of the curriculum of the Geography and History Division of the Faculty of Philosophy and Arts of the University of Seville of the subject 'Introduction to American History'. Nonetheless, shortly afterwards 'Anthropology' subjects were incorporated into the curricula of the Philosophy, Psychology and Education courses in the Faculty of Philosophy and Arts of the University of Seville by virtue of the Resolution of 30 June 1977. However, this was short-lived because the curricula were modified by the Order of 1 March 1979, which removed these subjects from the Education and Psychology degrees and modified the subject under the Philosophy degree, thereby frustrating its development in this university. Admittedly it gave rise to the first Anthropology post in an Andalusian university, although its profile was eventually described as 'Philosophical Anthropology'.

32 Resolution of 17 July 1986 of the University of Seville; Resolution of 3 December 1986 of the University of Seville.

${ }^{33}$ Agreement of 27 April 1988 of the Universities Council approving the Curriculum of the Faculty of Geography and History of the University of Seville.

${ }^{34}$ Resolution of 9 September 1994 of the University of Seville ordering the publication of the curriculum for the Bachelor's Degree in Social and Cultural Anthropology.

${ }^{35}$ Order of 7 February 1980 approving the curricula of the first and second cycles of the Philosophy and Psychology Sections of the Faculty of Philosophy and Arts of the University of Granada.

${ }^{36}$ Resolution of 1 September 1989 of the University of Granada ordering the publication of the Curriculum of the First Cycle of the Faculty of Political Science and Sociology of the University in the majors of Politics and Sociology.

${ }^{37}$ Resolution of 3 September 1990 of the University of Granada, appointing Mr Francisco Javier García Castaño as Senior University Lecturer attached to the area of knowledge of Social Anthropology.

${ }^{38}$ Resolution of 20 July 1999 of the University of Granada announcing the curriculum for the Bachelor's Degree in Social and Cultural Anthropology, to be taught in the Faculty of Philosophy and Arts of the University of Granada. 
${ }^{39}$ The year of defending the doctoral thesis was considered as the starting point of the university career of the teaching staff.

40 This includes students enrolled in the Bachelor's Degree in Geography and History (Social and Cultural Anthropology Section), as well as in the Bachelor's Degrees in Social and Cultural Anthropology at the Universities of Seville and Granada, the only ones to have offered this degree.

${ }^{41}$ The Social and Cultural Anthropology Section of the Bachelor's Degree in Geography and History had a duration of five academic years. It was replaced by the Bachelor's Degree in Social and Cultural Anthropology, which was a second cycle degree (two academic years) accessed from the first cycles (three academic years) of various degree courses, while the current Bachelor's Degrees in Social and Cultural Anthropology have a duration of four academic years.

\section{Copyright}

(c) () $\Theta($ This article is an open access article distributed under the terms and conditions of the ${ }_{\mathrm{EY}} \mathrm{NC}$ ND Creative Commons Attribution-NonCommercial-NoDerivatives 4.0 International License. 